\title{
Working
}

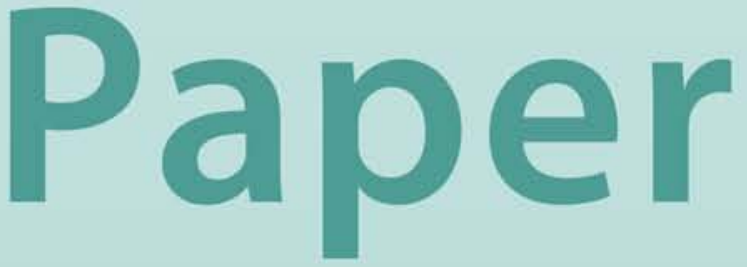




\section{Central Bank Financial Strength and Policy Performance: An Econometric Evaluation}

Ulrich Klüh and Peter Stella 


\title{
IMF Working Paper
}

\author{
Monetary and Capital Markets Department
}

\section{Central Bank Financial Strength and Policy Performance: An Econometric Evaluation}

\author{
Prepared by Ulrich Klüh and Peter Stella ${ }^{1}$
}

Authorized for distribution by Peter Stella

July 2008

\begin{abstract}

\section{This Working Paper should not be reported as representing the views of the IMF.} The views expressed in this Working Paper are those of the author(s) and do not necessarily represent those of the IMF or IMF policy. Working Papers describe research in progress by the author(s) and are published to elicit comments and to further debate.

The financial health of central banks and its relation to policy outcomes has recently been recognized as an important policy issue. While case study evidence clearly indicates that weak central bank finances can hamper effective policy implementation, the question of whether central bank financial strength influences policy performance remains controversial. This is due, in part, to a lack of econometric evidence. The paper presents a first step toward filling this gap, by providing a quantitative evaluation of the relationship between measures of central bank financial strength and policy performance, in particular inflation. The paper's major finding is that there indeed is a negative relationship between central bank financial strength and inflation outcomes. This relationship appears to be robust to the choice of alternative country samples, control variables, estimation strategies, and conceptualizations of central bank financial strength.
\end{abstract}

JEL Classification Numbers: E42, E52, E58, H63

Keywords: Central bank capital, central bank independence, inflation

Author’s E-Mail Address: uklueh@imf.org pstella@imf.org

\footnotetext{
${ }^{1}$ The authors would like to thank Alain Ize, Erlend Nier, and Ivan Luís Gonçalves de Oliveira Lima for helpful comments on an earlier draft.
} 
I. Introduction

II. Theoretical Considerations and Related Literature

A. Reasons for A Lack of Central Bank Financial Strength....................................... $\frac{5}{7}$

B. Theories Linking Central Bank Financial Strength and Policy Performance ........... 1

C. Related Empirical Evidence .............................................................................

III. Evaluating Cross-Country Indicators of Central Bank Financial Strength........................13

A. Conceptualization of Central Bank Financial Strength and Data Sources..............13

B. Recent Trends in Central Bank Profitability .................................................... 15

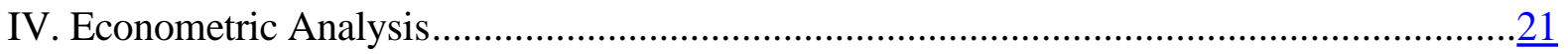

A. Data and Approach .........................................................................................

B. Central Bank Financial Strength and Inflation in a Panel of Latin American and

Caribbean Countries...........................................................................................24

C. Central Bank Financial Strength and Inflation in a Large Cross-Section of

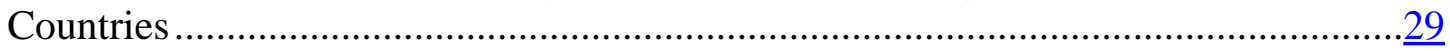

V. Policy Conclusions and Future Research................................................................

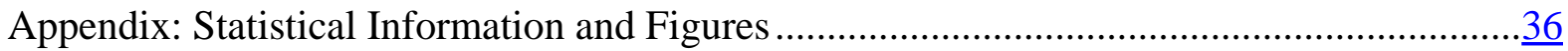

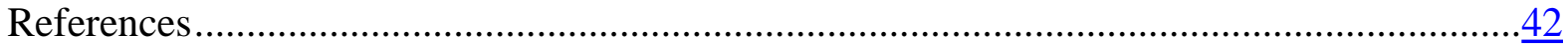

Tables

1. Baseline Results with Alternative Control Variables and Excluding Outliers ...................25

2. Fixed Effects Estimates with Alternative Control Variables ............................................ 26

3. Fiscal Variables and Alternative Dependent Variable.....................................................

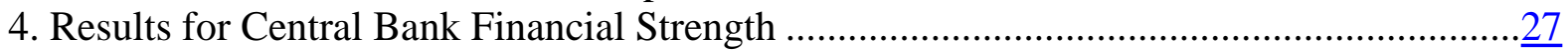

5. Feasible Generalized Least Squares Estimation ........................................................ 29

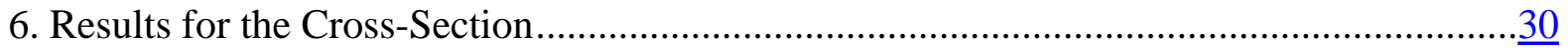

7. Accounting for Extreme Cases of Balance Sheet Distortions .........................................

Figures

1. Return on Average Assets in a Large Sample of Central Banks, 1995-2005 ....................16

2. Median Return on Average Assets in Bankscope Sample ..............................................16

3. Share of Central Banks with High Central Bank Financial Strength................................17

4. Share of Central Banks with Negative IFS Capital ....................................................18

5. Central Bank Financial Strength in a Group of Western Hemisphere Countries ................18

6. Distribution of Reported Sum of Capital and OIN in Percent of Total Assets....................19

7. Distribution of Reported OIN in Percent of Total Assets.............................................. $\frac{19}{20}$

8. Measures of Central Bank Revenues and Costs .............................................................20

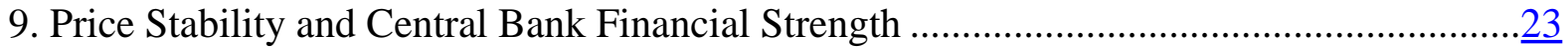

10. Relationship Between Central Bank Financial Strength and d......................................

11. Relationship Between Central Bank Financial Strength and d ......................................33 


\section{INTRODUCTION}

The capitalization and profitability of central banks has long been a relatively neglected topic. Recently, however, research into the nature, determinants and consequences of "weak" central bank balance sheets has grown considerably. This increased attention has its roots in at least six distinct developments:

(i) Increased international financial integration has led to greater attention being paid to emerging markets, where problems of weak central bank balance sheets have been much more prevalent. Consequently, concerns over these weaknesses, which have long been absent in G7 economies (see Stella, 2005) have also made their way into the conscience of the wider financial community. "Redemption from original sin", i.e., the increasing ability of emerging market governments to issue debt in local currency, has reinforced these tendencies, by making policymakers aware of the potential drawbacks of debt market fragmentation resulting from the circulation of central bank debt, and the potential role of central bank recapitalizations in jump-starting and deepening the domestic debt market.

(ii) The worldwide trend of lower inflation rates has partly eroded traditional central bank financing models (see section III below). A number of factors have accentuated the impact on central bank finances of this secular trend of lower seignorage revenues. In particular, increased price stability has sometimes been accompanied by major disruptions in financial sectors, with central banks assuming large amounts of problem assets, further weakening their balance sheet structure.

(iii) Large-scale foreign reserve accumulation by emerging markets has brought to the fore central banks' exposure to a major re-balancing of exchange rates. ${ }^{3}$ In addition to revaluation losses, the carrying cost implied by large-scale reserve accumulation currently represents a major financial burden to many central banks, further depressing income margins. As a result, in addition to its role in shaping a particular country's monetary policy stance, central bank financial strength (CBFS) is now being perceived as an issue with potentially global implications.

(iv) Recent financial market turbulence has highlighted the fact that even the balance sheets of mature market central banks can be subjected to potentially serious stress tests: In relatively short periods of time, tail events related to financial crises can materially change the risk profile of a central bank's asset-liability mix. This has also been clear from the debate surrounding the Bank of Japan's (BoJ) perceived

\footnotetext{
${ }^{2}$ This is visible, for example, in discussions of the importance of central bank recapitalization in country reports from credit rating agencies. See Fitch Ratings (2006), Reuters online (2007).

${ }^{3}$ See The Economist (2005).
} 
cautiousness to address deflation dynamics through the large-scale acquisition of long-term debt or foreign exchange (see below). ${ }^{4}$

(v) Closely related to these types of tail events, recent research into general equilibrium models of monetary policy has shown that price level determinacy can crucially depend on the public's beliefs about the dynamic properties of an economy following extreme disturbances, such as episodes of systemic stress, deflation, or hyperinflation (Sims, 2004). Avoiding explosive equilibria often requires assuming that fiscal behavior backs monetary policy actions in specific ways. However, fiscal theories of the price level have often been perceived as lacking a clear relation to real world phenomena. In this context, the experience of countries that have actually faced the decision of whether and how to "back" the central bank financially might provide valuable insights into the nature of balance sheet consolidation and policy cooperation within the fiscal-monetary sphere. ${ }^{5}$

(vi) The adoption of more transparent accounting standards by central banks worldwide, including fair value accounting for assets, has revealed far more volatility in equity than had hitherto been the case. ${ }^{6}$

The increasing number of studies that have been produced as a response to these developments has led to a much better understanding of the theoretical issues at stake, though open questions remain (see below). However, while many case studies show that weak central bank finances and disappointing policy outcomes indeed do coincide, aggregate empirical evidence on the importance of the central bank's financial health remains elusive and controversial. One of the main reasons for the disinclination to establish a (causal) link between central bank financial strength and macroeconomic performance has been a lack of econometric evidence. Existing work mainly relies on case studies and descriptive statistics, and does not always take into account the potential for reverse causality as well as observed and unobserved heterogeneity.

The paper attempts a first step toward filling this gap, by providing an econometric evaluation of the relationship between measures of central bank financial strength and policy outcomes. To perform the econometric evaluation, we use a variety of data sources and techniques, employing both cross section and panel data approaches. At the same time, the paper provides one of the first attempts to systematically study long-run trends in central bank profitability.

\footnotetext{
${ }^{4}$ See Cargill (2005), Ueda (2004) as well as Bernanke (2003).

${ }^{5}$ See Lonnberg and Stella (2008).

${ }^{6}$ The Bank of Canada has recently increased its authorized reserves to offset possible future valuation losses on its investment portfolio which may arise following its adoption of International Financial Reporting Standards. See Johnson and Zelmer (2007).
} 
The paper is organized as follows. Section II reviews related contributions on the causes and consequences of weak central bank balance sheets. It also points out the relation of our approach to the literature on institutional and organizational determinants of macroeconomic policy performance, with an emphasis on contributions looking at central bank independence. Section III gives a detailed account of available indicators of central bank financial conditions. By doing so, we provide not only the descriptive background of our analysis, but also what we believe are the major trends in central bank profitability. Section IV presents econometric results for both a panel-based approach and a larger cross-section of countries. Section V concludes.

\section{Theoretical Considerations AND Related Literature}

As mentioned above, recent years have seen a surge in the number of academic and applied contributions dealing with issues of central bank quasi-fiscal losses and the nature and role of monetary authorities' net worth. Abstracting from the actual implementation of central bank recapitalization schemes (see Stella, 2008, forthcoming), the issues that are discussed in this growing body of literature can be organized around three major questions: First: What are the causes that usually lead to weak central bank balance sheets? Second: What is, in theory, the relationship between central bank financial strength and policy outcomes? Third: What are, from an empirical perspective, the implications of leaving the central bank in the midst of a financially precarious situation, i.e., not addressing the underlying vulnerabilities?

\section{A. Reasons for A Lack of Central Bank Financial Strength}

With respect to the causes of pronounced deteriorations in a central bank's financial condition, the predominant view of many observers has long been that, given the nature of their assets and liabilities, central banks should usually be robustly profitable entities. ${ }^{7}$ It is therefore useful to first clarify the kind of circumstances that may lead to deteriorating balance sheets, and to identify the potential causes of protracted central bank losses, and net worth problems. Judging from the existing case study evidence ${ }^{8}$, central bank financial problems have often been associated with an external shock or policy decision that disproportionately inflates the monetary authority's balance sheet, which is subsequently characterized by an undesirable combination of financial flows. More specifically, the following causes of a deterioration in a central bank's financial conditions can be identified:

- The aftermath of episodes of systemic instability in the banking sector is often characterized by a need to absorb the additional liquidity that had been extended to ailing

\footnotetext{
${ }^{7}$ See Stella (2005), for a collection of statements reflecting this view.

${ }^{8}$ Dalton and Dziobek (2005) discuss the experience of Brazil, Chile, the Czech Republic, Hungary, Korea, and Thailand, and occasionally also refer to Bolivia, Guyana, Jamaica, Madagascar, Peru, the Philippines, The Gambia, and Turkey. Leone (1993) and Stella (2005) focus on Latin America, Markiewicz (2001) on transition economies.
} 
banks. Faced with such a situation of structural excess liquidity, central banks have to rely on the costly issue of debt certificates, the rollover of which may continue for years. Depending on the growth in money demand (which may itself be slowed by the credibility deficit implied by central bank losses) the central bank might end up in a constant struggle to preserve its credibility.

- Very often, balance sheet problems associated with banking sector fragility are aggravated by the fact that the increase in central bank liabilities is often mirrored in the assumption of problem assets. These assets not only expand the central bank's mandates, responsibilities, and potentially the overall cost of operations, they may also complicate severely the valuation of the central bank's equity.

- Similarly, episodes of prolonged deflation and asset slumps can force central banks to purchase very large amounts of low-yielding instruments, the value of which might fall substantially as soon as the economy recovers and interest rates increase. Such revaluation might reduce or even wipe out the central bank's net worth, creating an unwillingness to act decisively against deflationary tendencies. The most prominent example for such problems has been Japan, ${ }^{9}$ one of the first cases in which a central bank from the group of advanced countries has been perceived as “financially restrained."10 11

- Finally, many central banks have experienced cases of "fiscal abuse” (Fry, 1993), that is, attempts by other public institutions to externalize losses or costs using the central bank's balance sheet. The quasi-fiscal losses related to these cases differ from those related to the core operations of the central bank, as they result from operations whose effect could, in principle, be duplicated by budgetary measures in the form of an explicit tax, subsidy or direct expenditure. ${ }^{12}$

While all these developments represent major stresses to the central bank's balance sheet, recent years have witnessed the emergence of three main drivers: the build-up of large stocks of foreign reserves, the worldwide decline in inflation, and financial innovation and development. The actual and potential future implications of these trends will be discussed in the section III below.

\footnotetext{
${ }^{9}$ See Cargill (2005).

10 Japan also provides an interesting example of how the mere perception of existing restraints might influence available policy options: While it remains unclear if and to what extent the BoJ was actually restrained by risks to its balance sheet, the mere suspicion that this could have been the case is likely to have changed policy expectations, and thus available policy options.

${ }^{11}$ Central bank balance sheets were obviously constrained under the gold standard.

${ }^{12}$ See Mackenzie and Stella (1996), pp. 3 and 17 for a discussion of defining “quasi-fiscal operations.”
} 


\section{B. Theories Linking Central Bank Financial Strength and Policy Performance}

The wide range of circumstances under which central banks can end up in a financially weak situation suggests that financial distress is by no means a particularly rare or unlikely condition. Still, many observers argue that, theoretically, links between financial conditions, the monetary policy stance, and macroeconomic outcomes are unlikely to emerge. There are two ways to address these "irrelevance" assertions: (1) A pragmatic approach, emphasizing the complementary nature of political, economic and financial independence and (2) an approach that emphasizes theoretical considerations linking CBFS and policy performance.

The pragmatic approach starts with the observation that, as a matter of fact, central bankers in many countries appear to be concerned about the financial health of their institution. These concerns, in turn, are likely to be factored in when policy responses to inflation pressures are contemplated, in particular in situations in which balance sheet risks are already pronounced. As a consequence, financial constraints have the potential to reduce the aggressiveness of anti-inflationary policies, or result in attempts to transfer the cost of mopping up excess liquidity to the rest of the financial system, for example by increasing reserve requirements excessively.

From the pragmatic point of view, a number of motives can lead to an inclination to factor in CBFS in monetary policy decisions. On the one hand, these motives may result from the selfinterested behavior of central bank representatives. For example, low or even negative returns might negatively affect a central banker's reputation as a capable manager and bureaucrat. This might lead to direct utility losses for a central banker concerned about future employment opportunities or personal prestige. Similarly, other bureaucratic rents, such as the extension of central bank expenditures over and above what is needed to carry out the assigned tasks, might be more difficult to seek in a situation in which the central bank does not generate a stable flow of seignorage revenues.

On the other hand, actual public welfare concerns might lead to a trade-off between policy and financial goals. For example, a perceived inability to act as a capable banker might negatively affect the public's and the industry's confidence in the central bank. More importantly, a weak balance sheet has the potential to severely impair the relationship between monetary and other public authorities. First, it is argued that the central bank needs financial independence (i.e. a capital buffer and a sustainable source of revenue) to preserve its political and economic independence (see, for example, Hawkins, 2003). Approaching the government for funding implies a higher risk of interference with monetary policy, since political agents might be tempted to engage in horse trading activities. In such a situation, one would jointly observe a weak balance sheet and opportunistic monetary policies leading to inflation. Alternatively, fearing a more fundamental interference with its policies, the central bank might opt to limit the chance of being "intervened" by choosing to act less aggressively ex ante. Second, a low degree of CBFS can be viewed as the by-product of fiscal dominance (Fry, 1998): The government's need for seignorage transfers precludes aggressively addressing inflation when central bank revenues fall below a certain threshold. 
In other words, the independence of the central bank is mirrored in its ability to sterilize fiscal policy actions, a policy course that is constrained by the need to generate seignorage.

In practice, the relevance of both accounts should not be discounted, as case study evidence suggests that the respective mechanisms have often played a central role. In theory, however, one could argue that the first argument puts the cart before the horse. A capital injection would only be needed if capital has an economic function, and it would be circular to argue that this function could be just the prevention of a capital injection. The second argument, in turn, could be characterized as one which does not deal with CBFS per se, but with fiscal dominance more broadly: A weak balance sheet is merely the outcome or indication of a more fundamental problem, namely the inability of the government to finance itself in a sustainable fashion in combination with a lack of political and economic independence. As a consequence, an empirical relation between CBFS and policy performance would be purely spurious, as it merely reflects the correlation between the actual reason for inflation (unsustainable fiscal policies) and the central bank’s financial health.

To assess these issues from a more theoretical angle, it is useful to first summarize the alternatives a loss-making central bank has at its disposal when the treasury does not provide for a capital injection, and does not want to engage in policies that would inflate away its debt. ${ }^{13}$ As a first option, the central bank can rely on measures intended to lower the cost of its monetary operations. In many cases, this is done using the institution's ability to adjust minimum reserve requirements. However, choosing this option involves economic costs, in particular with respect to financial development, as do other "financially repressive” policies, such as coercing banks to hold central bank paper not reflecting market yields.

A second option for the central bank is to use its ability to create money, using the interestfree liabilities it can use to pay for its obligations. If the resultant excess liquidity is not sterilized, money market rates will fall, finally leading to additional inflationary pressures. If, in contrast, the central bank mops up the resultant excess liquidity by issuing debt certificates offering an interest rate consistent with price stability, it will incur additional interest expenditures, and the described process is perpetuated (Ernhagen et al., 2002). ${ }^{14}$ Under plausible assumptions, however, losses would not go on indefinitely. As long as the demand

\footnotetext{
${ }^{13}$ See Bindseil et al. (2004) as well as Stella (2005). Some observers refuting the adverse effect of central bank negative net worth argue that the treasury would not even allow the situation to deteriorate in the described way. They argue that in the event of prolonged losses, it would always step in, replenishing the central bank's capital base. For example, Meltzer (1999) states that "No central bank has ever faced default, and no responsible government would permit that to happen. It is unclear to me what could be meant by failure of a central bank."

${ }^{14}$ Ernhagen et al. (2002) argue that the central bank has to finance itself by issuing accelerating debt certificates. The exact nature of "perpetuation" of central bank losses, however, depends on the exact model specification. Under reasonable assumptions, Bindseil et al. (2004) show that the central bank's debt will grow at a steady rate, even if banknotes in circulation disappear as a result of financial innovation. In Bindseil's model, central banks operating in a deterministic environment will always return to profitability as long as the growth rate of banknotes exceeds the growth rate of operating costs, regardless of the initial level of capital or operating costs.
} 
for currency in circulation grows at sufficiently high rates relative to the growth in operating costs, the central bank will eventually return to profitability. However, even if the situation is perpetuated indefinitely, this would not necessarily imply that monetary policy effectiveness would be nil. It might only place a lower bound on the steady state rate of inflation.

Experience shows that countries such as Chile have faced prolonged periods of central bank financial difficulties without direct transfers from the treasury, and without resorting to inflationary policies. In the case of Chile, however, the treasury effectively sterilized central bank losses by depositing its large central government surpluses at the central bank. Thus, the central bank was subject to what Stella (2005) has called "benevolent" fiscal dominance. The central question then becomes: Why and under what circumstances would a central bank not be able or willing to suffer financial losses to meet its policy objectives and instead rely at least partly on expansionary monetary policy, financial repression, or a combination of both?

On the one hand, meeting a given inflation target without resorting to massive financial repression may be-in some balance sheet situations—simply infeasible. In such a situation changes in public perceptions of the central bank's status, and in particular its very long-term ability to ensure price stability and continue to use its monopoly rights to issue currency may be crucial:

- As pointed out by Bindseil et al. (2004), the key to understanding the fragility of sustaining perpetual losses is to acknowledge that central banks operate in an institutional set-up in which neither a complete separation from, nor a complete consolidation with the rest of the government's balance sheet is eternally credible. Were it true in the former case, and assuming that complete separation implies complete independence in the sense of never being stripped of its right to issue currency, perpetual losses might be feasible. Similarly, complete consolidation would imply that the public will not pay attention to central bank finances, but to the aggregate No-Ponzi condition of the state. In intermediate situations however, the central bank might well find itself unable to continuously mop up the liquidity created to cover up losses, because the buyers of central bank securities will fear interference from the treasury.

- An additional feasibility condition is that the rules and mechanics of the debt accumulation game between the central bank and the public would have to be common knowledge, an assumption that might not always hold. If only some parts of the public do not understand the irrelevance argument outlined above, self-fulfilling dynamics may emerge. In fact, an equilibrium of perpetuation could become infeasible just because there is uncertainty about the ability of other players to fully grasp the nature of the game. More generally, any theory that postulates the impossibility of an illiquid central bank has to deal with the fragile nature of trust in a currency's purchasing power, and the potential perception that central banks' liabilities have to be backed by valuable assets.

On the other hand, and apart from feasibility considerations, it might just be the case that the seemingly costless policy of perpetuation does involve costs in practice. To identify these 
costs, it is useful to distinguish between a central bank maximizing a social welfare function, and a group of central bank representatives behaving at least partly as self-interested bureaucrats. In the former case, the central bank might fear that a policy of perpetuation may involve significant costs to society. For example, the existence of two important issuers of "sovereign" domestic public debt can under certain conditions impede the development of a unified and liquid market for government securities, seen by many as a prerequisite for financial market development.

Apart from market segmentation, conflicts of interest arise when monetary and debt management are handled within the same organization. This includes challenges to policy communication, in particular when the central bank has to explain the adverse impact of its own monetary policy decisions on debt management performance. In addition, the general reputation of a central bank might suffer from continuing losses, that is, the mere perception that the central bank might be poorly managed can have adverse macroeconomic consequences (see Vaez-Zadeh, 1991).

Turning to the case of a partly self-interested bureaucrat, it is possible to imagine a wide range of situations in which a precarious financial situation might lead to a less aggressive approach toward inflation. In his seminal contribution, Rogoff (1985, p. 1180) refers to such cases, in pointing out that:

“...it would be desirable to have a central bank's operations financed in such a way that its expenditures are independent of the government's seignorage revenue. (It is interesting to observe that during the high inflation years of the late sixties and the seventies, architecturally stunning new Federal Reserve buildings sprouted up all over the United States.)"

In one of the few studies on the topic, Ize (2006) studies the relationship between seignorage income and operational expenditures. He finds that central banks indeed adjust operating expenditures upward as profitability increases. This implies, among other things, that there might be "soft budget constraint” concerns related to central banks. More importantly, Ize’s results suggest that financially weak central banks, which tend to be less independent financially and still are used as "residual sources of cheap [government] finance", are characterized by more pronounced governance problems. Consequently, incentives to rely on the expandability of seigniorage revenues might be particularly pronounced.

While a number of recent contributions study the implications of career or financial motives in central banking, the existing literature largely neglects the role of financial structure in determining incentives. Approaches building on Walsh (1995) generally assume that the central bank's loss function is identical to the social one, so incentive problems merely emerge from concerns related to dynamic inconsistency. Approaches that depart from this assumption (e.g., Frisell et al., 2004, and Eggertsson and Le Borgne, 2004) do not analyze the role of CBFS, even though the kind of "ego rents" incorporated in these models would provide a natural starting point for related considerations. 
In sum, a number of arguments support the view that an undercapitalized central bank will have difficulties to implement a low-inflation equilibrium. All of these arguments are bound together through the fact that the boundaries between the central bank and the rest of government are not easily defined either in policy, or accounting senses. Policy areas that call for a separation of responsibilities co-exist with policy areas in which close cooperation is necessary, for example in debt management and treasury cash management; giving the central bank independence over the pursuit of price stability implies handing over partial control over variables the central government might want to control, such as the level and volatility of the exchange rate, or the size of seignorage transfers in situations of fiscal dominance. Alternatively, some of the mechanisms put forward within fiscal theories of the price level might be present. Within the institutional set-up that structures this complex relationship, CBFS is one of the variables where these areas of cooperation or conflict are apparent.

\section{Related Empirical Evidence}

The preceding analysis shows that existing theories of monetary policy support the view that a lack of CBFS can impede the pursuit of price stability. Still, opponents of this view have provided a range of valuable arguments, in particular with respect to the consolidated nature of the public sector's balance sheet. Whether the central bank's stand-alone balance sheet itself has a role to play in determining macroeconomic policy outcomes can thus not be finally resolved by theory. Against this background, surprisingly few studies attempt to analyze the empirical link between CBFS and policy performance. Ize (2006) regresses an index of central bank's expenditure performance (the residual of a regression explaining expenditures by a number of central bank characteristics) on various measures of macroeconomic and financial stability. He finds a positive relationship between excess expenditures and the level of inflation, although at a very low level of significance. Stella (2008) provides t-statistics comparing the inflation performance of financially weak and strong central banks, using a stock measure of CBFS and data from IFS (see below). He finds that the difference in performance is pronounced, and statistically highly significant.

While the mentioned contributions provide some first evidence on a positive relationship between CBFS and inflation, their analysis remains largely descriptive, and do not control for other factors potentially affecting policy outcomes. The reportedly negative correlation between measures of CBFS and inflation is thus potentially spurious. To our knowledge, none of the existing studies has so far attempted to quantify the effects of CBFS, taking into account the possibility that it might be jointly determined with inflation or other factors affecting it. The purpose of this paper is precisely to fill this gap, by providing first econometric evidence with respect to the macroeconomic consequences of weak central bank finances.

By doing so, the paper also relates to the broader area of research dealing with the identification of institutional and organizational determinants of cross-country variations in macroeconomic policy outcomes, in particular inflation. Since we use a cross-country sample 
covering most world regions as well as a panel of Latin American countries, it is useful to briefly review the main results from other studies in these two areas. This allows us to identify a set of suitable control variables as well as some methodological caveats potentially affecting our results.

Regarding cross-country evidence on the determinants of policy performance, most recent contributions agree that it has been difficult to econometrically establish a causal link between legal and de facto measures of central bank independence and inflation (Arnone, Laurens and Segalotto, 2006a,b provide an extensive survey of the literature). Results are sensitive to the exclusion of outliers, the use of different measures of constitutional, legal or de facto independence, the choice of control variables as well as the underlying sample. Nonetheless, most studies agree that independence, most likely in combination with other structural and macroeconomic reform efforts, contributes to credibility, which in turn is central in achieving low inflation. ${ }^{15}$ The exact nature of interaction with other variables, however, remains unclear. While the respective roles of openness (Romer, 1993), the exchange rate regime (Alfaro, 2003), and measures of institutional quality and economic development are thus still debated, most researchers would agree that they represent suitable controls.

Large cross-country studies usually do not refer to central bank financial autonomy as a separate factor. For Latin America and the Caribbean, however, Jácome (2001) decomposes an overall index of independence into economic, political and financial sub-indices. Interestingly, he finds that higher values of "economic" and "financial” independence are associated with lower inflation outcomes, while a general index of legal independence yields counter-intuitive results. Other studies using panel methods and data from Latin America include Gutiérrez (2003) and Jácome and Vázquez (2005). These studies use different indicators for central bank independence, but a similar set of control variables, namely a dummy for the occurrence of a systemic banking crisis, a variable describing the exchange rate regime, and, in Jácome and Vázquez (2005), a variable capturing the world-wide trend to lower inflation rates. Gutiérrez (2003) finds that countries with larger constitutional central bank independence tended to have lower inflation rates. Jácome and Vázquez (2005), using variants of the Cukierman (1992) and Grilli, Masciandaro and Tabellini (1991) index, suggest that, after controlling for endogeneity, no causal link between legal independence and inflation can be established. However, the majority of their regressions would imply a negative relationship, which only disappears after including a measure of structural reforms, which often coincided with an increase in legal independence. Consequently, the authors suggest that the pursuit of independence has to be viewed in the broader policy context.

\footnotetext{
${ }^{15}$ A vast literature uses cross-country data to identify determinants of inflation, and we do not attempt to provide an exhaustive survey. Campillo and Miron (1996) study the role of a large number of potential control variables in a joint model. Their findings suggest that "economic fundamentals" (in particular openness and optimal tax considerations) may outperform indicators of the institutional framework, such as central bank independence and the exchange rate regime.
} 


\section{EVAluATING Cross-Country INDiCATORS OF CENTRAL BANK FINANCIAL STRENGTH}

\section{A. Conceptualization of Central Bank Financial Strength and Data Sources}

Probably the most fundamental obstacle to an econometric investigation of CBFS is the availability, reliability and comparability of data. Not only do central bank accounting practices vary greatly among different countries and over time; they also typically involve "non-standard" approaches to the valuation of specific balance sheet items, in particular in the case of valuation gains and losses and when it comes to accounting for certain financial relationships with the government and other public entities.

As a consequence, central bank financial statements do not lend themselves easily to an econometric investigation. Given the lack of international standardization, a specific accounting value for central bank capital might well signal sufficient strength in one country, but financial distress in another. Moreover, central bank losses have often been accounted for with lags - the consequences of a weak balance sheet might thus be observed in periods where measured financial strength is still apparently high. Finally, trends in central bank accounting standards, such as the recent tendency to increasingly use mark-to-market valuation, may lead to systematic changes in the whole sample of countries. This might be particularly troublesome since more sensitive accounting practices have been introduced in parallel with a worldwide decline in inflation, thus leading to a potential downward bias for parameter estimates.

Perhaps more fundamentally, theories of central bank financial strength do not provide clear guidance as to which of the potential measures should be used when assessing the relation between a central bank's financial condition and macroeconomic outcomes. One of the few contributions that tries to operationalize the concept of CBFS is Ize (2005), who derives an expression for central banks' net worth and its relation to inflation outcomes. Most importantly, this analysis shows that "adequate net worth" has to be understood in terms of the volatility of the macroeconomic environment and the target inflation rate, where a more volatile setting and a more ambitious objective lead to higher net worth requirements. Such an approach would suggest using a stock measure of central bank capital, and controlling for elements of the central bank's objective function, including exchange rate-related issues.

However, accounting capital will only be a very imperfect proxy for net worth. Implicit liabilities (for example from high cost-low probability financial stability events) and assets (in particular the exclusive right to issue currency, and the expected income streams derived from it) are not recorded in typical accounting frameworks, even though they might easily dwarf accounting items (Stella, 2008). Moreover, anecdotal evidence suggests that, even if appropriately measured, a stock concept might not fully capture the implications of CBFS. In particular, it is not unlikely that transitory profitability problems also impact a central bank's approach to macroeconomic stabilization. 
To deal with these problems, it is advisable to employ more than one data source, and more than a single quantitative conceptualization of CBFS. Consequently, for econometric purposes, we use four different sets of information from three different sources, one trying to capture the net worth of central banks (CBFS as a stock concept), two proxies of central bank profitability (CBFS as a flow concept), and one measure of accumulated losses in preceding years: ${ }^{16}$

- To construct a stock measure of CBFS, we follow Stella (2008) and calculate the sum of Central Bank Capital (CBC) and Other Items Net (OIN), using data from the IMF's International Financial Statistics as well as data from the underlying "Monetary and Banking Statistics". The resultant figure is then scaled using central bank Total Assets (TA). The most important advantage of this dataset is its wide-ranging coverage and the fact that the inclusion in IFS involves a certain degree of standardization. A disadvantage is that the measure

$$
\mathrm{CBFS}_{1 \mathrm{t}}=\left(\mathrm{CBC}_{\mathrm{t}}+\mathrm{OIN}_{\mathrm{t}}\right) / \mathrm{TA}_{\mathrm{t}}
$$

is only an imperfect proxy for CBFS, as it might capture other relevant characteristics of the monetary authorities. In particular, a large ratio of OIN to TA may also signal low central bank transparency or insufficient data quality.

- To check the robustness of results obtained with this measure, we obtained data on central bank's Return on Average Assets (ROAA) from Bankscope. ${ }^{17}$ A peculiar problem of the resulting measure

$$
\mathrm{CBFS}_{2 \mathrm{t}}=\mathrm{ROAA}_{\mathrm{t}}
$$

is the large variation in coverage: While more recent years contain information on a large sample of countries (up to 131), the information in early years, particularly before 1995, is scattered. We account for this problem by presenting the information both for the whole sample and for a sample excluding the countries without a minimum number of observations (three per five-year period). For other information obtained from Bankscope, we use a similar procedure.

- For a smaller set of countries in Latin America and the Caribbean, we obtained information on central bank profits and losses (CBINCOME) for the period 1987-2005, expressing them as a percentage of GDP (see Table A3 in the Appendix): ${ }^{18}$

\footnotetext{
${ }^{16}$ Table A1 in the Appendix summarizes our four conceptualizations of CBFS.

${ }^{17}$ In addition, we obtained Bankscope data on central bank's net income and expressed it as a ratio to total assets at the end of a financial year. For the large majority of countries, this measure does not deviate from ROAA, owing to the fact that most central banks only publish annual accounts.
} 


\section{$\mathrm{CBFS}_{3 \mathrm{t}}=\mathrm{CBINCOME}_{\mathrm{t}} / \mathrm{GDP}_{\mathrm{t}}$}

Starting from the information in Leone (1994), which consists of data for the period 1987-1992, we used publicly available IMF staff reports, and, in a few cases, information provided by country authorities, to extend country and period coverage. A particular advantage of this data is that it has been scrutinized and checked, either by IMF country teams or, as in the case of the Dominican Republic, by country authorities preparing a central bank recapitalization plan. Moreover, the data lends itself more easily to a panel study, and thus allows us to more closely examine issues of endogeneity, for example by simply lagging our measure of CBFS. A disadvantage may be that coverage is limited, and potentially biased toward those countries in which CBFS has been an issue of policy relevance. However, by trying to expand coverage, we hope to have addressed these problems.

- Finally, and using the data on central bank financial results in Latin America and the Caribbean, we calculated a measure of accumulated losses over a specified period of time, using a moving window of 2, 3 and 4 years, respectively. The measure

$$
\mathrm{CBFS}_{4 \mathrm{t}}=\sum_{\mathrm{t}-1}^{\mathrm{t}-\mathrm{n}} \mathrm{CBINCOME}_{\mathrm{t}} / \mathrm{GDP}_{\mathrm{t}}
$$

will be used to cross-check econometric results, and is not discussed in the next section.

\section{B. Recent Trends in Central Bank Profitability}

We mentioned in section II above that recent years have seen a number of secular developments that might exert substantial pressure on the profitability of central banks worldwide. While a number of observers have raised concerns about these developments, the underlying trends remain largely undocumented. This section attempts to fill this gap, by providing a cross-country perspective on secular trends in central bank financial conditions, and their relation to major macroeconomic developments.

\footnotetext{
${ }^{18}$ To calculate the fiscal stance of the consolidated public sector of Latin American countries member countries, most IMF staff reports separately display central bank gains/losses.
} 
Figure 1. Return on Average Assets in a Large Sample of Central Banks, 1995-2005 (In percent of total assets)

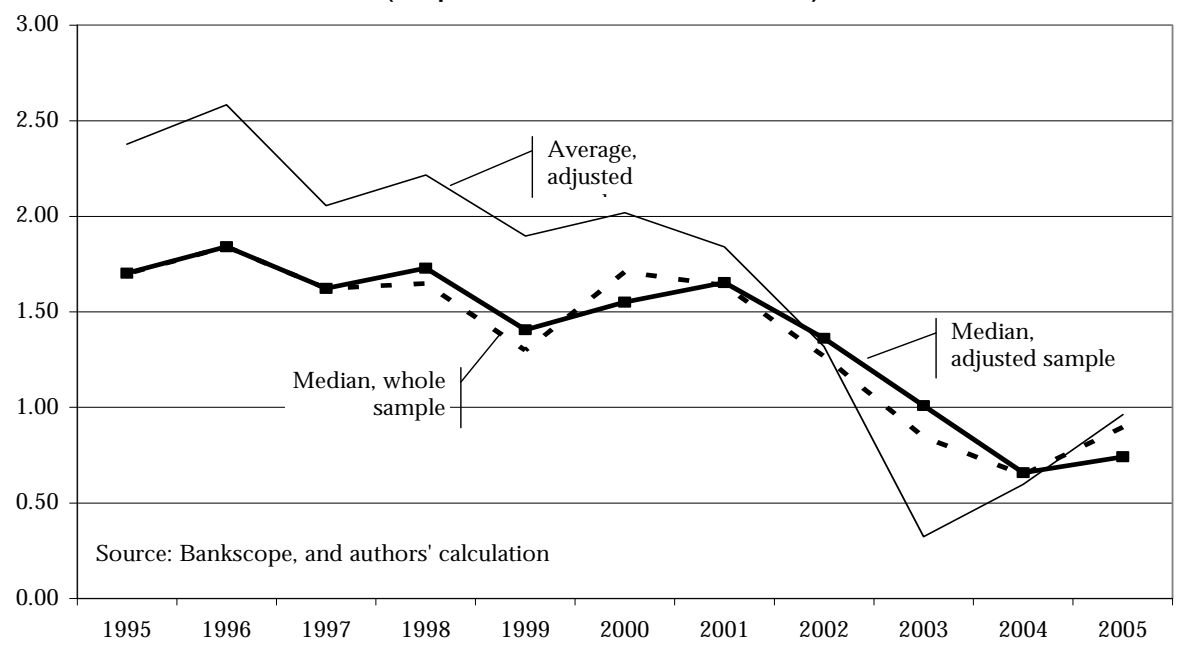

As a first step, Figure 1 to 5 summarize global trends in central bank financial conditions, using the three data sources considered. Figure 1 and 2 show central bank's ROAA in a sample of more than 130 countries between 1995 and 2005. Since, for many countries, data from Bankscope is not available for earlier years, we plot the median and average value for each year for the whole sample together with median for the countries that provide data for at least 9 of the 11 years considered (91 countries). Figure 3 and 4 present data from IFS on the capital to asset ratio as well as on our measure of financial strength. ${ }^{19}$ Finally, Figure 5 shows central bank results as a percentage of GDP for Latin America and the Caribbean since 1990.

Figure 2. Median Return on Average Assets in Bankscope Sample (Five-year averages)

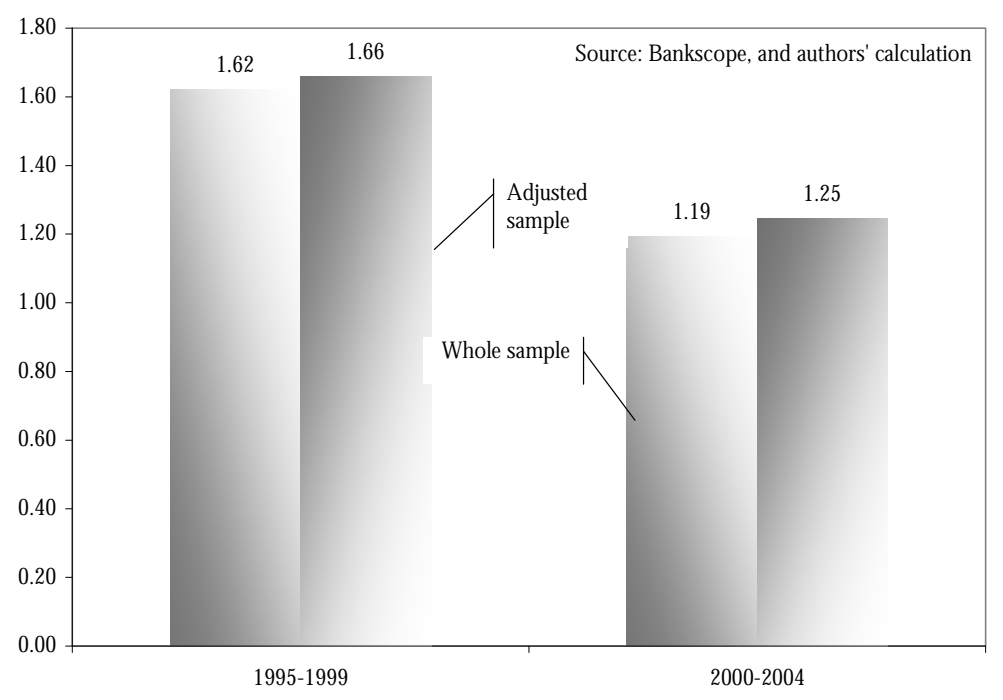

\footnotetext{
${ }^{19}$ Countries in which the ratio of capital and other items net to total assets exceeds 20 are defined as those with high CBFS.
} 
From Figure 1 and 2, it is obvious that recent years have seen a trend decline in central bank profitability: For empirical purposes, it is encouraging that all three datasets, though quite different in nature, show a similar pattern, with the decline in CBFS starting at least in the late 1990s. Using the Bankscope data, the median return on assets has declined from around 2.5 percent in 1995 to substantially less than 1 percent in 2005 . For the adjusted sample, the five year average of the median return on assets declined from 1.66 percent in the second half of the 1990s to 1.25 in the first half of the current decade (Figure 2).

Figure 3. Share of Central Banks with High Central Bank Financial Strength (In percent of all central banks in sample)

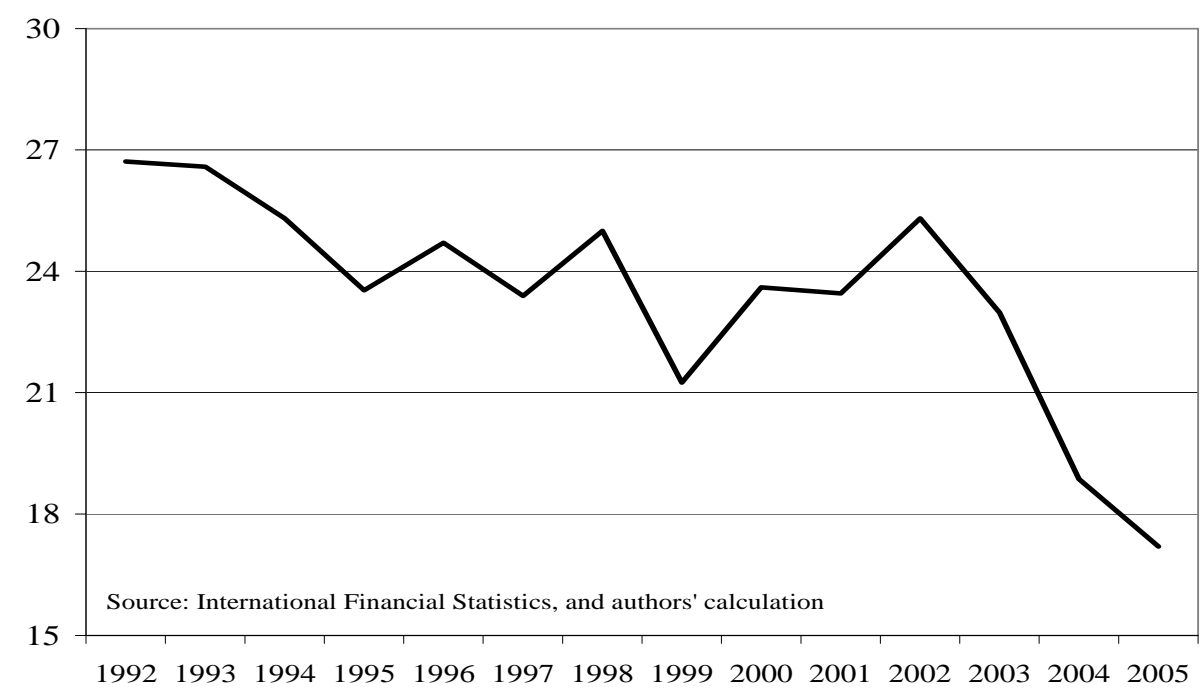

A similar pattern can be observed when looking at the share of countries with exceptionally strong (weak) IFS balance sheets in Figure 3 and 4, respectively. The share of central banks with very high net worth (Figure 3) declined from more than 25 percent in 1992 to around 15 percent in 2005. Within the same period, the share of central banks that reported a negative capital account in IFS (Figure 4) has increased from less than two to more than eight percent. In Latin America and the Caribbean, the observed recuperation during the 1990s has been reversed since then (Figure 5). 
Figure 4. Share of Central Banks with Negative IFS Capital (In percent of all central banks in sample)

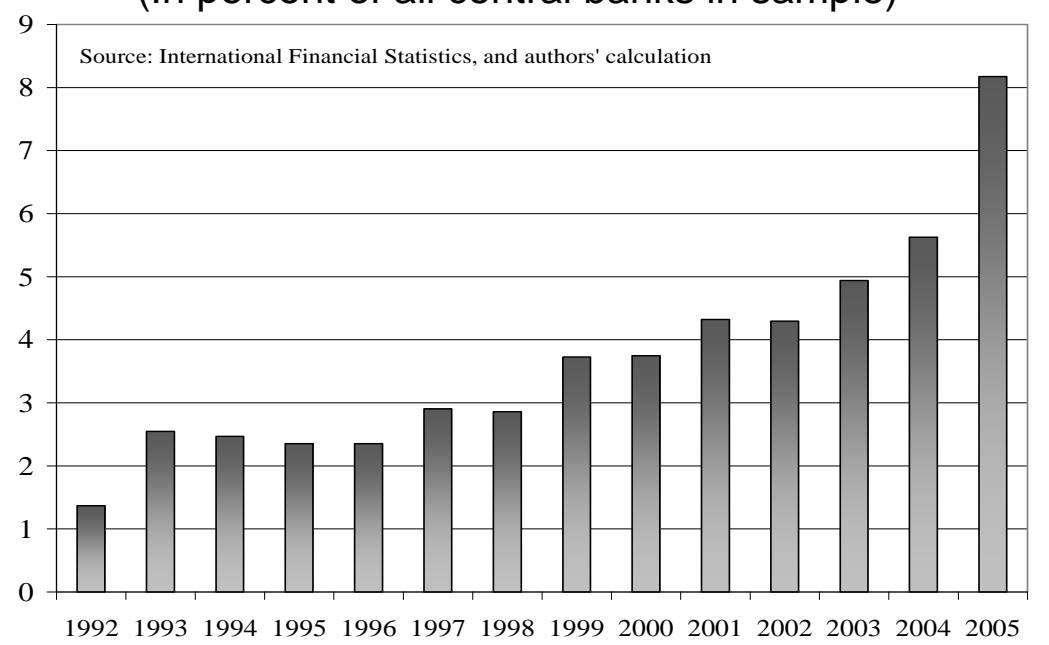

For the IFS data, there are indications of yet another trend, one which may partly explain the increase in countries reporting negative capital. Accounting procedures seem to have become more reflective of economic reality in recent years, as evidenced by a decreasing share of countries with very high OIN (Figure 6 and 7). Apparently, national and multilateral efforts to increase transparency and statistical reporting, for example through the IMF's safeguards assessment program, have been effective. It is worth noting that this trend might influence our econometric analysis below, as time-variant measurement error might be present.

Figure 5. Central Bank Financial Strength in a Group of Western Hemisphere Countries

(In percent of GDP)

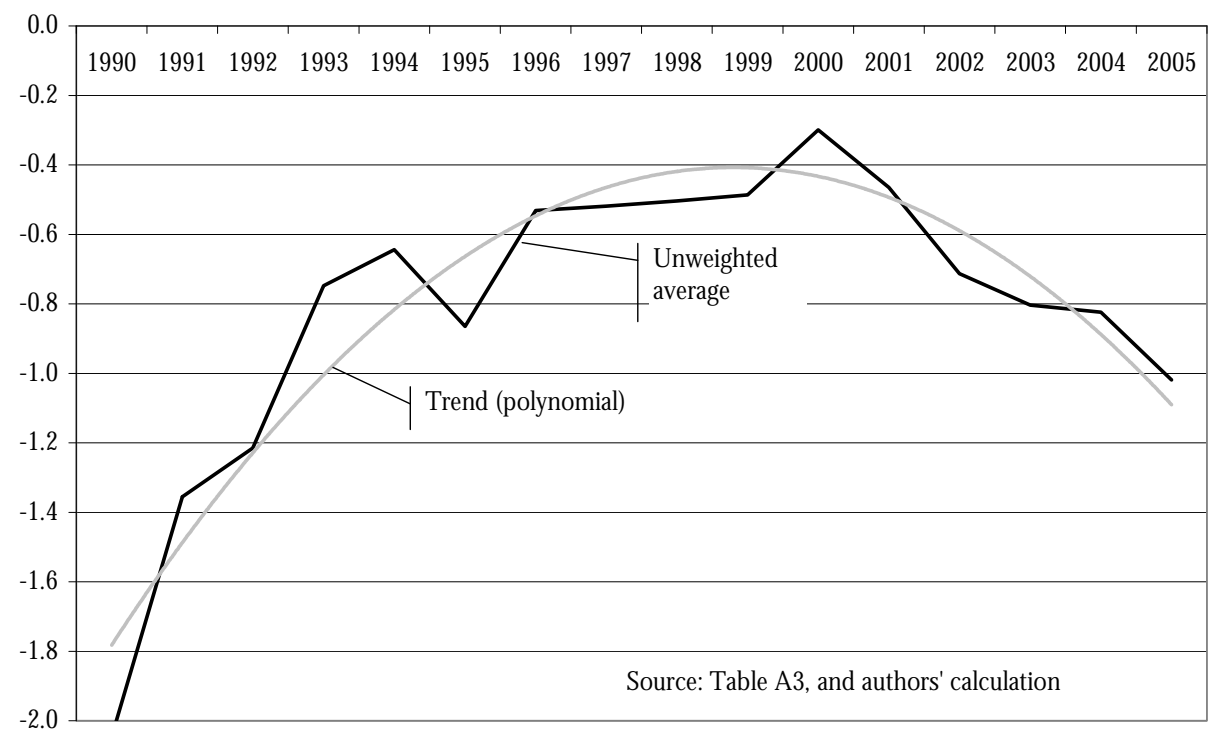


Figure 6. Distribution of Reported Sum of Capital and OIN in Percent of Total Assets (Number of countries)

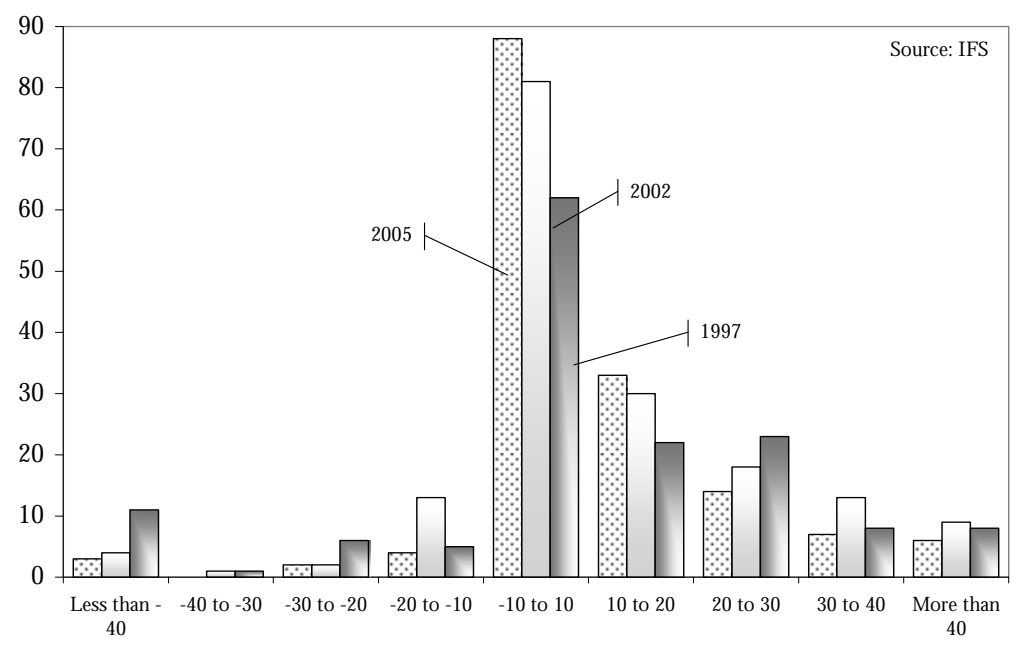

What explains the trend of declining profitability? While a full assessment would exceed the scope of this paper, a first issue worth noting is that it does not seem to be a clustering of extreme losses or major adverse shocks to central bank balance sheets (for example, the event of major bank rescue operations or episodes of "fiscal abuse") that lies behind the secular decline in profitability. Quite in contrast, recent years have seen a decrease in cases of sudden and extreme quasi-fiscal losses. As can be seen from Figure 6, the number of countries that display extreme negative values for $\mathrm{CBFS}_{1}$ has declined over time. While part of this development might be explained by the improvement in central bank accounting practices, a look at the information for Latin America and the Caribbean (Table A3 in the appendix), where central bank losses had been particularly pronounced, suggests that there have been sustained efforts to improve the income situation of the respective central banks.

Figure 7. Distribution of Reported OIN in Percent of Total Assets (Number of countries)

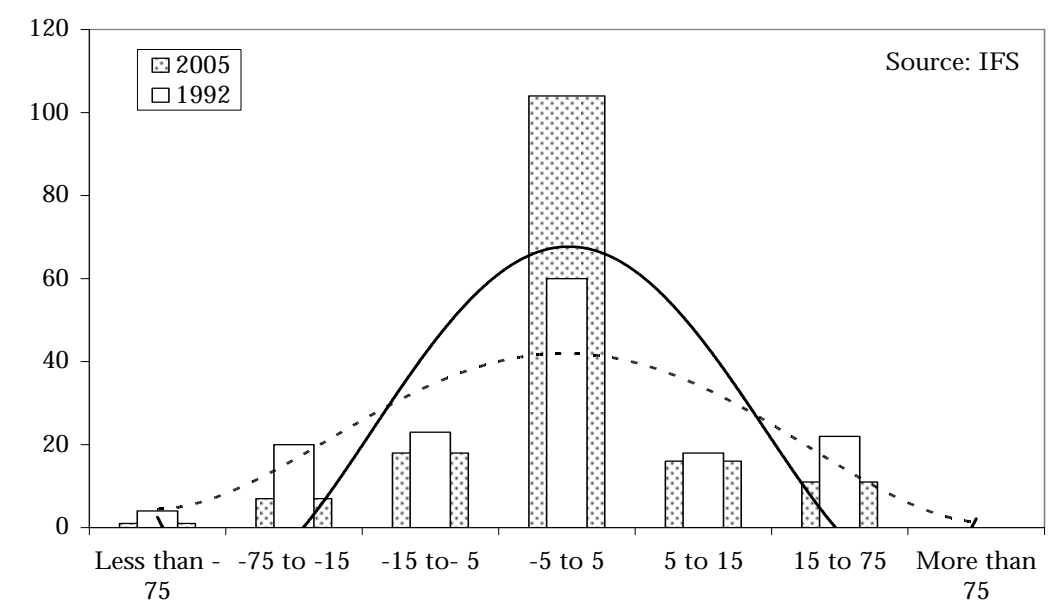

A number of other observations support this view. In many developing and emerging countries, inflation has declined from hyperinflationary levels, leading to a resurgence of money demand and thus revenue streams. At the same time, structural reforms aimed at 
strengthening central bank independence have in many cases limited the scope for extreme cases of fiscal abuse (Arnone et al., 2006). Finally, the number of systemic banking crises, which had spiked in the 1980s and 1990s has come down substantially since the end of the 1990s, the period in which profitability had started to decline.

If it is not the clustering of major adverse shocks to central bank balance sheets, what lies behind declining profitability? To answer this question, it is useful to take a closer look at central banks' income statements. From Figure 8, it is clear that net interest margins have been experiencing a marked decline since the mid-1990s (upper left panel). At the same time, central banks have not been able to compensate decreasing interest margins with other operating income. In contrast, other income sources appear to have declined in importance quite substantially (lower left panel). While attempts to limit non-interest expenditures have been partly successful (upper right panel), they were not substantive enough to prevent a substantial increase in central banks' cost to income ratio.

Figure 8. Measures of Central Bank Revenues and Costs
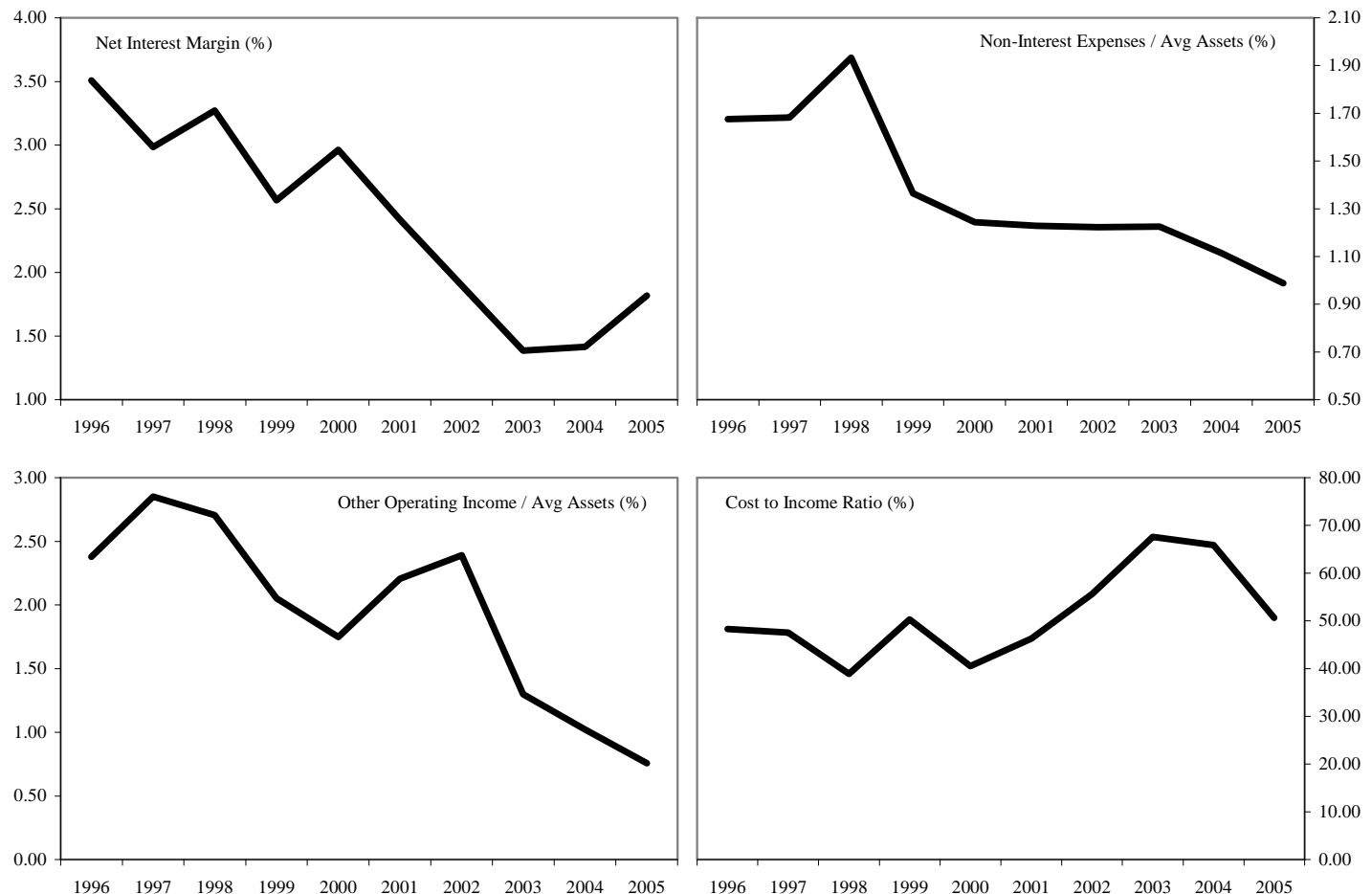

Source: Bankscope

The overall decline in central bank interest revenues that seems to drive these developments has been largely attributed to two major factors:

- The worldwide decline in inflation rates, coupled with a decreasing inclination to hold currency, has probably been the major driving force behind declining profitability. In the sample of 100 countries studied by Ize (2006), average inflation has fallen from around 14 percent in the period 1985-1995 to around 7 percent in the following decade, while currency holdings as a percentage of GDP have declined by around 1.5 percentage points. 
- Especially in recent years, countries that experienced large-scale capital inflows have often relied on the accumulation of substantial amounts of reserves on the central bank's balance sheet. This build-up of reserves, in turn, may impact the institutions' financial health through two distinct channels. First, it can lead to revaluation losses should global exchange rates re-balance. Second, the reserve build up has led to a sustained increase in carrying cost, as the yield on the instruments used to sterilize reserve growth has often exceeded the yield on foreign exchange reserve holdings.

What are the implications of the described developments? If it is really the case that central banks operating at low or negative profit margins face greater obstacles to ensure price stability, a continuation of current trends might soon represent one of the more important threats to the improved inflation performance in many countries. The monetary authorities' success in bringing inflation down might thus set the seeds for inhibiting them to do the same in the future. Consequently, it could become necessary to re-think current financing models for central banks, ensuring that they can rely on a stable income stream to finance monetary policy operations. Certainly, such a proposal would face substantial opposition, in particular because, as mentioned above, few studies exist that empirically assess the issue.

\section{ECONOMETRIC ANALYSIS}

\section{A. Data and Approach ${ }^{20}$}

To evaluate the impact of CBFS on macroeconomic outcomes, we focus on regressions with a measure of price stability as the dependent variable. In a first step, we employ a panel data set for Latin America and the Caribbean spanning from 1987 to 2005, and including 15 countries. ${ }^{21}$ As the underlying data on CBFS has been scrutinized extensively, and the panel nature of the data allows for a more elaborate treatment of unobserved heterogeneity, we use the respective results as our benchmark estimate. In a second step, we turn to a large cross-section of 176 countries (all countries for which information on CPI inflation is available in IFS). This enables us to position our estimates alongside the large literature on inflation and central bank independence. The unavailability of data on CBFS and/or other covariates (in particular central bank independence) implies that sample size is reduced substantially, to less than 100 countries depending on the exact specification (see below).

For the dependent variable, we use data from the IFS database to calculate CPI inflation rates for the period 1987 to 2005 . As discussed extensively in the empirical literature on central bank independence (see, for example, Cukierman, 1992), using actual inflation rates is likely to result in heteroscedastic error terms, mostly due to the presence of hyperinflationary outliers. In addition to actual inflation, we therefore use the rescaled measure $\quad d=\frac{\pi_{t}}{\left(1+\pi_{t}\right)}$,

\footnotetext{
${ }^{20}$ See Table A2 in the appendix for a description of the data and its sources. Table A4 and A5 provide pair-wise correlations for both samples.

${ }^{21}$ From originally 25 countries, 10 are excluded due to missing information on either CBFS or other covariates.
} 
which ranges from 0 to 1 , and can be interpreted as the rate of depreciation of purchasing power. To check whether the bounded nature of this variable (and the resulting violation of the normality assumption) decisively affects our estimates, we finally check robustness using the $\log$ of $\left(1+\pi_{t}\right)$. For the panel analysis, we use yearly data from 1987 to 2005 . For the crosssection, we follow the empirical literature on central bank independence, calculating long-term average inflation over the period 1992 to 2005.

Our main explanatory variables are the measures of CBFS discussed in section III above. In studying the relation between the central bank's financial position and inflation, it is important to take into account that inflationary pressures themselves can cause financial weakness by forcing a central bank to carry out costly stabilization strategies. If these pressures are large and persistent, one might jointly observe high inflation and weakening financial position, just because the central bank is reacting in an optimal but gradual approach, and the financial consequences of its policies occur more promptly than the macroeconomic ones. While it is worth mentioning that the negative income effects of inflationary shocks might be partly offset by higher seignorage income, at least along the first segment of the inflation tax Laffer curve, any econometric evaluation has to account for potential reverse causality. When using panel data, we therefore lag our measures of CBFS by one period. Figure 9 plots our measure of inflation against the lagged measures of central bank income as a percent of GDP $\left(\mathrm{CBFS}_{3}\right)$, both for each country and for each time period. ${ }^{22}$

Any econometric evaluation of the impact of central bank financial strength on inflation and other variables should take into account that variations on both sides of the equation might have common root causes, thus making the relationship inherently spurious. From a crosscountry perspective, the same country characteristics that may lead to high inflation can potentially lead to a weak central bank balance sheet, without a causal link between the two. Similarly, time trends in the data, in particular the secular decline in inflation experienced during the observation period, have to be taken into account. As long as these characteristics are observed with sufficient precision, the matter boils down to a sensible choice of control variables. ${ }^{23}$ In choosing covariates, we were mainly guided by the literature on the long-term determinants of inflation, in particular the numerous studies on central bank independence.

For panel estimation purposes, we use data on central bank independence, trade openness, the degree of economic development as measured by GDP per capita, institutional quality, the exchange rate regime, and a dummy for the occurrence of banking crises in a specific period. Our choice of covariates is partly inspired by the studies of Jácome and Vázquez (2005), partly by other studies on central bank independence. Finally, we account for the worldwide trend decline in inflation by including the average inflation rate of the G7 countries. While a detailed description of data sources as well as descriptive statistics can be found in the appendix, it is worth mentioning that all of our explanatory variables display at least some variation over time.

\footnotetext{
${ }^{22}$ Figure A1 in the Appendix shows the respective graphs for the variable $\mathrm{CBFS}_{4}$.

${ }^{23}$ As soon as unobserved heterogeneity comes into play (such as the abilities of decision-makers), panel techniques might offer some, although imperfect, remedies which we discuss below.
} 
This includes information on central bank independence (CBI), which we take from Jácome and Vázquez. We also compare results for different measures of CBI.

Figure 9. Price Stability and Central Bank Financial Strength
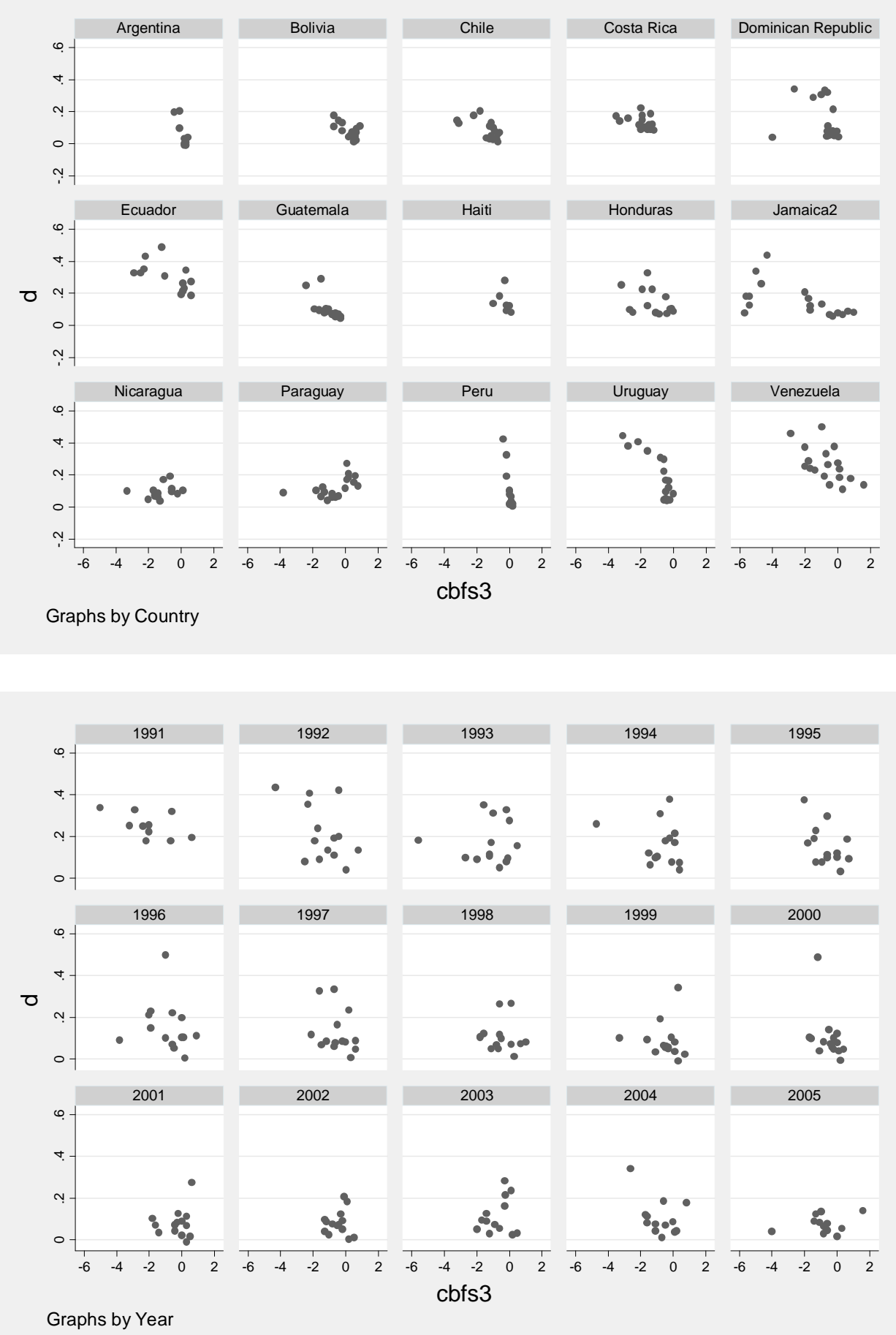
For the cross-section, issues of data availability become much more pronounced, forcing us to reduce the number of covariates substantially. We therefore focus on openness, institutional quality, GDP per capita, and CBI. For both approaches, it is worth pointing out that CBFS might not only relate to inflation directly, but also reinforce other determinants of inflation outcomes. In particular, the effects of a lack of political or legal independence might be larger in situations in which the central bank does not have access to sufficient funding. To account for this effect, we include interaction terms.

Finally, it is worth noting that a lack of central bank financial strength may result in policy responses that neutralize part or all of its effect on inflation performance, at the cost of the emergence of other policy distortions. Consequently, observing that a financially weak central bank succeeds in stabilizing inflation does not necessarily imply that macroeconomic performance remains unaffected. In particular, central banks can rely on measures of financial repression, for example through the use of excessively high reserve requirements. Policy dilemmas related to weak balance sheets might thus not only translate into higher inflation, but also into other distortions. While, in parallel work, we plan to study the effects of CBFS on measures of financial repression and debt market development (using data from Arena, Reinhart, and Vázquez, 2006), for the current paper we would argue that any estimate of the relation between CBFS and inflation should expected to be downward biased.

\section{B. Central Bank Financial Strength and Inflation in a Panel of Latin American and Caribbean Countries}

Tables 1 to 5 summarize results based on the panel data covering 15 countries in Latin America and the Caribbean. ${ }^{24}$ As a first step, we estimated pooled OLS regressions, using lagged measures of central bank financial strength (conceptualized as $\mathrm{CBFS}_{3}$ ) as well as a core set of control variables (central bank independence, inflation developments in industrialized countries, institutional quality, the exchange rate regime, and the level of economic development). OLS estimates indicate a stable negative relationship between CBFS and inflation, which appears to be robust to the inclusion of additional control variables, such as the level of economic openness, and a dummy for the occurrence of a banking crisis (columns 2 and 3 of Table 1). Goodness-of-fit measures indicate that a relatively large part of the variance in inflation is explained by the model, and most covariates have the expected sign. Results also appear to be robust to the use of alternative measures of central bank independence and institutional quality (columns 4-6 of Table 1). Substituting our preferred measure (based on Cukierman's methodology) with sub-indices of political or economic independence, a modified index based on Jácome and Vázquez (2005) or a variable capturing central bank turnover do not alter substantially the relationship between CBFS and price stability (columns 4 and 5 of Table 1).

\footnotetext{
${ }^{24}$ Throughout the description of econometric results, we use robust standard errors.
} 
Table 1. Baseline Results with Alternative Control Variables and Excluding Outliers

\begin{tabular}{|c|c|c|c|c|c|c|c|}
\hline & 1 & 2 & 3 & 4 & 5 & 6 & 7 \\
\hline Dependent & \multicolumn{7}{|c|}{$d$} \\
\hline Estimation & \multicolumn{7}{|c|}{ Pooled OLS } \\
\hline $\mathrm{CBFS}_{3, \mathrm{t}-1}$ & $-.019 * \star$ & $-.032^{\star \star \star}$ & $-.029^{\star \star \star}$ & $-.034^{\star \star \star}$ & $-.020^{\star \star}$ & $-.036^{\star \star \star}$ & $-.027^{\star \star \star}$ \\
\hline World inflation & $.054^{\star \star \star}$ & $.040^{\star \star \star}$ & $.046^{\star \star \star}$ & $.037^{\star \star \star}$ & $.058^{\star \star \star}$ & $.062^{\star \star \star}$ & $.030^{\star \star \star}$ \\
\hline \multicolumn{8}{|l|}{$\mathrm{CBI}$} \\
\hline Cukierman overall & $-.159^{\star \star \star \star}$ & $-.261^{\star \star}$ & $-.230^{\star \star \star}$ & & & $-.312^{\star \star \star}$ & $-.221^{\star \star \star}$ \\
\hline Cukierman economic & & & & $-.154^{\star \star \star}$ & & & \\
\hline CB Turnover Rate & & & & & 0.053 & & \\
\hline \multicolumn{8}{|l|}{ Institutions } \\
\hline Overall & $-.011^{\star \star \star}$ & $-.010^{\star \star \star}$ & $-.009 * \star \star$ & 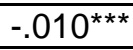 & $-.011^{\star \star \star}$ & & $-.005^{\star \star \star}$ \\
\hline Dem. Acc. & & & & & & $.030^{\star \star \star}$ & \\
\hline Fixed regime & $-.063^{\star \star}$ & $-.067^{\star \star}$ & $-.057^{\star \star}$ & $-.073^{\star \star}$ & $-.091^{\star \star \star}$ & -.031 & -.037 \\
\hline GDP per capita & $.000^{\star \star \star}$ & $.000^{\star \star \star}$ & $.000^{\star \star \star}$ & $.000^{\star \star}$ & $.000^{\star \star \star}$ & .000 & $.000^{\star \star \star}$ \\
\hline Openness & & $-.002^{\star \star \star}$ & $-.002^{\star \star \star}$ & $-.002^{\star \star \star}$ & $-.001^{* \star}$ & $-.003^{\star \star \star}$ & $-.001^{\star \star \star}$ \\
\hline Banking crisis & & & $.128^{\star \star \star}$ & $.121^{\star \star \star}$ & $.168^{\star \star \star}$ & $.146^{\star \star \star}$ & $.064^{\star \star}$ \\
\hline Observations & 242 & 237 & 237 & 206 & 174 & 237 & 227 \\
\hline$R$-squared & .60 & .57 & .61 & .62 & .62 & .56 & .44 \\
\hline
\end{tabular}

More importantly, excluding hyper- and high-inflationary episodes from the sample does not impact the substance of our findings: While coefficient estimates for CBFS do react to the exclusion of country-year observations in which inflation exceeded 1000 percent, they remain significant, at least at the 5 percent confidence level (column 7 of Table 1). The same is true if we exclude observations exceeding an inflation rate of 500 and 100 percent (not shown). Nonetheless, and following Jácome and Vázquez (2005), we exclude hyperinflationary observations (with inflation in the respective period exceeding 1000 percent) in the following regressions.

In a next step, we run fixed effects regressions of the same type. While pooled OLS results are useful as a first approximation to the potential relationship between CBFS and inflation outcomes, obtaining consistent parameter estimates would at least require orthogonality between explanatory variables and unobserved components. In the current setup, however, unobserved heterogeneity is likely to result in time constant individual effects to be correlated with observed covariates. A priori, using a within transformation (i.e., fixed effects at the country level) seems a reasonable strategy for the sample at hand, as it consists of a relatively large share of the underlying population. Table 2 presents within estimators, which are largely consistent with the findings discussed with reference to Table 1. Again, column 1 to 3 represent results for alternative combinations of covariates, columns 4-6 results for alternative measures for central bank independence and institutional quality, and column 7 results for a sample excluding hyperinflationary episodes, which represents our baseline specification. 
Table 2. Fixed Effects Estimates with Alternative Control Variables

\begin{tabular}{|c|c|c|c|c|c|c|c|}
\hline & 1 & 2 & 3 & 4 & 5 & 6 & 7 \\
\hline Dependent & \multicolumn{7}{|c|}{$d$} \\
\hline Estimation & \multicolumn{7}{|c|}{ Fixed Effects } \\
\hline $\mathrm{CBFS}_{3, \mathrm{t}-1}$ & $-.038^{\star \star \star}$ & $-.033^{\star \star \star}$ & $-.031^{\star \star \star}$ & 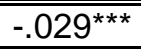 & $-.018^{\star \star}$ & $-.036^{\star \star *}$ & $-.021^{\star \star}$ \\
\hline World inflation & .013 & .013 & .020 & .015 & $.029^{\star}$ & $.048^{\star \star \star}$ & $.008^{\star \star}$ \\
\hline \multicolumn{8}{|l|}{ CBI } \\
\hline Cukierman overall & $-.260^{\star \star \star}$ & $-.256^{\star \star \star}$ & $-.244^{\star \star \star}$ & & & $-.306^{\star \star \star}$ & $-.201^{\star \star}$ \\
\hline Cukierman economic & & & & 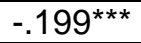 & & & \\
\hline CB Turnover Rate & & & & & .018 & & \\
\hline \multicolumn{8}{|l|}{ Institutions } \\
\hline Overall & $-.010^{\star \star \star}$ & $-.010^{\star \star \star}$ & $-.009^{\star \star \star}$ & $-.010^{\star \star \star}$ & $-.011^{\star \star *}$ & & $-.006^{\star \star \star}$ \\
\hline Dem. Accountability & & & & & & $.023^{\star \star}$ & \\
\hline Fixed regime & $-.069 \star \star$ & $-.066^{\star}$ & -.055 & $-.074^{\star}$ & $-.148^{\star \star \star}$ & -.057 & -.012 \\
\hline GDP per capita & -.000 & $-.000^{*}$ & -.000 & -.000 & -.000 & $-.000^{\star \star}$ & $-.000^{\star \star \star}$ \\
\hline Openness & & $.004^{\star \star \star}$ & $.003^{\star \star \star}$ & $.003^{\star \star \star}$ & $.004^{\star \star \star}$ & $.003^{\star \star \star}$ & $.003^{\star \star \star}$ \\
\hline Banking crisis & & & $.083^{\star \star \star}$ & $.081^{\star \star}$ & $.112^{\star \star \star}$ & $.102^{\star \star \star}$ & .030 \\
\hline Observations & 242 & 237 & 237 & 206 & 174 & 237 & 227 \\
\hline$R$-squared (within) & .61 & .63 & .64 & .67 & .70 & .59 & .50 \\
\hline
\end{tabular}

An important caveat of the analysis so far is that large central bank losses over a number of years might merely reflect a fiscal crisis, inflation pressures resulting from expansionary fiscal policies, and more generally a deterioration in consolidated public sector finances. To take fiscal policies into account, we include a measure of the central government's overall deficit in our regressions. The results (reported as Specification B in Table 3), do not appear to change markedly. Similarly, results do not appear to be sensitive to our choice of the dependent variable, as the regression using the $\log$ of $\left(1+\pi_{t}\right)$ yields essentially similar results (Specification C in Table 2).

Because of the use of a lagged yearly flow variable for CBFS, our results could be mainly driven by major unobserved events for which we do not account. Moreover, a single year of losses should in fact not represent a major impediment to anti-inflationary policies, as it is a sustained weakening of central bank finances that drives the theoretical mechanism discussed above. ${ }^{25}$ To check how far our results would change if this is taken into account, we replace the dependent variable $\mathrm{CBFS}_{3}$ with a measure of the accumulated losses over the preceding three years $\left(\mathrm{CBFS}_{4}\right)$. This reduces the number of observations somewhat, as we have to exclude the first two observations for each panel. Independent of the exact specification, the use of $\mathrm{CBFS}_{4}$ does not materially affect the negative relationship identified above. Indeed, coefficient estimates appear to be more stable, and consistently significant at the one percent level (Table 4, columns 1-4). Moreover, the size of the reduction in the coefficient estimate is broadly consistent with the difference in economic interpretation between $\mathrm{CBFS}_{3}$ and $\mathrm{CBFS}_{4}$.

\footnotetext{
${ }^{25}$ Neither applying random effects nor including year dummies changes our results materially.
} 
Table 3. Fiscal Variables and Alternative Dependent Variable

\begin{tabular}{|c|c|c|c|c|c|c|}
\hline & \multicolumn{2}{|c|}{$\begin{array}{c}\text { Specification A } \\
\text { (Baseline-all) }\end{array}$} & \multicolumn{2}{|c|}{$\begin{array}{c}\text { Specification B } \\
\text { (Fiscal) }\end{array}$} & \multicolumn{2}{|c|}{$\begin{array}{c}\text { Specification C } \\
\text { (Baseline II) }\end{array}$} \\
\hline \multirow[t]{2}{*}{ Dependent } & \multicolumn{2}{|c|}{$d$} & \multicolumn{2}{|c|}{$d$} & \multicolumn{2}{|c|}{$\left(1+\pi_{t}\right)$} \\
\hline & $\begin{array}{c}\text { Pooled } \\
\text { OLS } \\
\end{array}$ & $\begin{array}{c}\text { Fixed } \\
\text { Effects }\end{array}$ & $\begin{array}{c}\text { Pooled } \\
\text { OLS }\end{array}$ & $\begin{array}{c}\text { Fixed } \\
\text { Effects }\end{array}$ & $\begin{array}{c}\text { Pooled } \\
\text { OLS } \\
\end{array}$ & $\begin{array}{c}\text { Fixed } \\
\text { Effects } \\
\end{array}$ \\
\hline $\mathrm{CBFS}_{3, \mathrm{t}-1}$ & $-.027 * * *$ & $-.021 * *$ & $-.025 * *$ & $-.017^{*}$ & $-.055^{* *}$ & $-.047 * *$ \\
\hline World inflation & $.030 * * *$ & .008 & $.031 * * *$ & -.004 & $.030 *$ & -.006 \\
\hline CBI & $-.222 * * *$ & $-.201 * *$ & $-.235 * * *$ & $-.236 * *$ & $-.394 * * *$ & $-.440 * *$ \\
\hline Institutions & $-.005 * * *$ & $-.006 * * *$ & $-.005 * * *$ & $-.007 * * *$ & $-.010 * *$ & $-.011 * * *$ \\
\hline Fixed regime & -.037 & -.012 & -.041 & -.018 & $-.073 *$ & -.0288 \\
\hline GDP per capita & $.000 * *$ & $-.000 * * *$ & .000 & $-.000 * *$ & $.000 * *$ & $-.000 *$ \\
\hline Openness & $-.001 * * *$ & $.003 * * *$ & $-.002 * * *$ & $.002 * * *$ & $-.003 * * *$ & $.004 * * *$ \\
\hline Banking crisis & $.064^{* *}$ & .0296 & $.063 * *$ & .019 & $.101^{*}$ & .056 \\
\hline Deficit & & & .005 & $.007 *$ & & \\
\hline "Observations & 227 & 227 & 206 & 206 & 227 & 227 \\
\hline $\begin{array}{l}R \text {-squared } \\
\text { (overall/within) }\end{array}$ & .44 & .53 & .46 & .56 & .40 & .45 \\
\hline
\end{tabular}

Table 4. Results for Central Bank Financial Strength 4

\begin{tabular}{|c|c|c|c|c|c|c|}
\hline \multirow{3}{*}{ Dependent } & \multicolumn{2}{|c|}{$\begin{array}{c}\text { Specification CBFS }_{3} \\
\text { (Baseline) }\end{array}$} & \multicolumn{2}{|c|}{$\begin{array}{c}\text { Specification } \mathrm{CBFS}_{4} \\
\text { (Baseline) }\end{array}$} & \multicolumn{2}{|c|}{$\begin{array}{c}\text { Specification CBFS } \\
\text { (Fiscal) }\end{array}$} \\
\hline & & & & & & \\
\hline & $\begin{array}{l}\text { Pooled } \\
\text { OLS }\end{array}$ & $\begin{array}{c}\text { Fixed } \\
\text { Effects }\end{array}$ & $\begin{array}{l}\text { Pooled } \\
\text { OLS }\end{array}$ & $\begin{array}{c}\text { Fixed } \\
\text { Effects }\end{array}$ & $\begin{array}{l}\text { Pooled } \\
\text { OLS }\end{array}$ & $\begin{array}{l}\text { Fixed } \\
\text { Effects }\end{array}$ \\
\hline $\mathrm{CBFS}_{3, \mathrm{t}-1}$ & $-.027^{\star \star \star}$ & $-.021^{\star \star}$ & & & & \\
\hline $\mathrm{CBFS}_{4, \mathrm{t}-1}$ & & & $-.008^{* * *}$ & $-.007^{* \star *}$ & $.008^{\star \star \star}$ & $-.005^{\star \star}$ \\
\hline World inflation & $.030 * \star \star$ & .008 & $.045^{\star \star \star}$ & $.022^{\star \star}$ & $.043^{\star \star \star}$ & .008 \\
\hline $\mathrm{CBI}$ & $-.222^{\star \star \star}$ & $-.201^{\star \star}$ & -.150 ** & -.074 & $-.157^{\star \star}$ & -.104 \\
\hline Institutions & $-.005^{\star \star \star}$ & $-.006^{\star \star \star}$ & $-.006^{\star \star \star}$ & $-.007 * \star \star$ & $-.005^{\star \star \star}$ & -.008 \\
\hline Fixed regime & -.037 & -.012 & $-.042^{\star}$ & .007 & $-.043^{\star}$ & .007 \\
\hline GDP per capita & $.000^{\star \star}$ & $-.000 * \star \star$ & $.000^{*}$ & 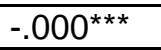 & .000 & -.000 \\
\hline Openness & $-.001^{\star \star \star}$ & $.003^{\star \star \star}$ & $-.001^{\star}$ & $.003^{\star \star \star}$ & $-.001^{*}$ & .002 \\
\hline Banking crisis & $.064^{\star \star}$ & .0296 & $.051^{\star \star}$ & .018 & $.048^{\star}$ & .004 \\
\hline Deficit & & & & & .004 & $.006^{\star}$ \\
\hline Observations & 227 & 227 & 203 & 203 & 184 & 184 \\
\hline $\begin{array}{l}R \text {-squared } \\
\text { (overall/within) }\end{array}$ & .44 & .53 & .44 & .55 & .44 & .58 \\
\hline
\end{tabular}

We perform a range of specification tests to examine the adequacy of our identification strategies. As our summary tables do not report F-statistics for tests of the joint significance of the set of "country fixed effects" included in Table 2 and 3, a first point worth mentioning is that the null hypothesis of no joint significance can be rejected throughout. More specifically, there are good reasons to believe that, after excluding hyperinflationary observations, OLS estimates are biased upwards, an assertion also supported by the results displayed in Table 3 and 4 . Nonetheless, while the specification based on a within 
transformation yields somewhat lower parameter estimates than those obtained using pooled OLS, the effect of higher CBFS on policy performance remains sizeable. ${ }^{26}$

Next, we carry out a likelihood ratio test for heteroscedasticity across panels. Large differences between restricted and unrestricted models suggest that heteroscedasticity is indeed likely to be present. Moreover several tests for autocorrelation in the fixed effects model imply that serial correlation cannot be ruled out. ${ }^{27}$ Based on these findings, we repeat our estimation using Feasible Generalized Least Squares (FGLS) regressions that take into account heteroscedasticity and autocorrelation (Table 5). Under the assumption of heteroscedasticity across panels, and imposing a common AR(1) coefficient for all panels, the negative coefficient for CBFS remains significant in most specifications, in particular when accumulated central bank losses are used. However, results are now more sensitive to the exclusion of hyperinflationary episodes and the inclusion of trending variables such as world inflation. In particular, the coefficient on $\mathrm{CBFS}_{3}$ in column 4 becomes insignificant. Overall, however, results for a broad range of alternative specifications remain consistent with an inverse relationship between CBFS and inflation performance. ${ }^{28}$

In sum, there appears to be a relatively stable and negative relationship between CBFS (as measured by either previous year's central bank profits as a percentage of GDP or accumulated central bank profits) and inflation, at least for the sample of Latin American and Caribbean countries considered here. Of course, the above results are only a first step toward establishing a robust link. In particular, it would be desirable to address issues of endogeneity more directly. While the use of lagged values for $\mathrm{CBFS}_{3}$ (and partly the use of $\mathrm{CBFS}_{4}$ ) can reduce the potential for reverse causality, finding an improved instrument for CBFS would represent an important next step.

\footnotetext{
${ }^{26}$ It is unlikely that regression analysis in the current context yields reliable estimates of the size of the potential inflation reduction associated with a given improvements in central bank finances. Nonetheless, our coefficient estimates suggest that the relationship between CBFS and inflation outcomes is not merely statistically, but also economically significant. To illustrate the respective dimensions, it is useful to consider a simple example. Given the non-linear relationship between the inflation rate and $d$, the impact of higher CBFS on inflation performance can only be determined approximately, and for a given starting value for inflation. For example, for a country in which the inflation rate runs at 25 percent, the results in column 2 of Table 3 would imply that a recapitalization that transforms a central bank loss of one percent of GDP into a surplus of one percent would result in a decline in inflation by six percentage points.

${ }^{27}$ For our preferred set of control variables (columns 1 and 2 in Table 3) a Wooldridge test for autocorrelation yields an F-value of 25.6. For the null hypothesis of no first-order autocorrelation, the respective $p$-value is 0.0002 .

${ }^{28}$ We also carried out a series of regressions based on the Generalized Method of Moments (GMM). Again, results from a linear dynamic panel-data estimation à la Arellano-Bond are consistent with the hypothesis that higher CBFS facilitates the maintenance of a low inflation environment.
} 
Table 5. Feasible Generalized Least Squares Estimation

\begin{tabular}{|c|c|c|c|c|c|c|}
\hline & \multicolumn{3}{|c|}{ WHOLE SAMPLE } & \multicolumn{3}{|c|}{ EXCLUDING HYPERINFLATION } \\
\hline & 1 & 2 & 3 & 4 & 5 & 6 \\
\hline $\mathrm{CBFS}_{3, \mathrm{t}-1}$ & $-.013^{\star \star}$ & & $-.018^{\star \star \star}$ & -.007 & & $-.013^{\star \star}$ \\
\hline $\mathrm{CBFS}_{4, \mathrm{t}-1}$ & & $-.011^{\star \star \star}$ & & & $-.004^{\star}$ & \\
\hline World inflation & $.040^{\star \star \star}$ & $.032^{\star \star \star}$ & & $.032^{\star \star \star}$ & $.034^{\star \star \star}$ & \\
\hline $\mathrm{CBI}$ & $-.139 \star \star$ & $-.137^{\star \star}$ & $-.151^{\star \star}$ & $-.010^{\star}$ & $-.101^{\star \star}$ & $-.130^{\star \star}$ \\
\hline Institutions & $-.007^{\star \star \star}$ & $-.006^{\star \star \star}$ & $-.007^{\star \star \star}$ & $-.003^{\star \star \star}$ & $-.004^{\star \star \star}$ & $-.004^{\star \star \star}$ \\
\hline Fixed regime & -.019 & -.016 & -.020 & -.007 & -.006 & -.011 \\
\hline GDP per capita & .000 & $.000^{*}$ & .000 & .000 & .000 & .000 \\
\hline Openness & -.001 & -.001 & -.000 & .000 & .000 & .000 \\
\hline Banking crisis & $.036^{\star \star}$ & .024 & .026 & .020 & .015 & .011 \\
\hline Observations & 237 & 206 & 237 & 226 & 202 & 226 \\
\hline Wald chi2 & 129.37 & 163.09 & 86.28 & 77.92 & 116.58 & 49.18 \\
\hline Common AR(1) & .63 & .52 & .59 & .60 & .49 & .58 \\
\hline
\end{tabular}

Another source of concern is that the underlying sample is relatively small, and potentially subject to selection bias. In future work, it would therefore be desirable to expand coverage, both over time and geographically. Finally, estimations so far have been based on a relatively volatile measure of CBFS that only partly takes into account the stock dimension of a central bank's financial condition. For these reasons, in a second step, we turn to an analysis of CBFS and inflation in a larger cross-section, comparing the results using a proxy for central bank capitalization with those based on a measure of central bank profitability.

\section{Central Bank Financial Strength and Inflation in a Large Cross-Section of Countries}

The major objective of the cross-sectional analysis is to extend coverage to a much larger and more diverse set of countries. One of the major drawbacks of such an attempt is that data limitations are much more pronounced. In particular, we are not aware of data on central bank independence covering such a large number of countries. For this reason, we proceed by first estimating regressions that only employ widely available covariates typically used in regressions of inflation on structural variables. We then compare results for our two alternative measures of CBFS, one based on stock variables from IFS ( $\left.\mathrm{CBFS}_{1}\right)$, and one based on return information from Bankscope $\left(\mathrm{CBFS}_{2}\right)$. In a final step, we check robustness using the central bank turnover rates used in De Haan and Sturm (2001), which covers a broad set of countries and has the additional advantage of having been calculated for the 1990s specifically.

The first two columns in Table 6 present OLS estimates for two baseline cases, in which we regress $d$ on $\mathrm{CBFS}_{1}$ using two alternative specifications: One in which we control for institutional quality and openness, and one in which we add GDP per capita as an additional control variable. Moreover, the analysis excludes all observations in which average inflation over the whole period exceeded 100 percent. Both in the first and in the second case, all variables have the expected sign, and countries characterized by a higher value for CBFS 
tend to be characterized by lower inflation. Not unexpectedly, the overall explanatory power is relatively low. While adding the additional control reduces the parameter estimate for CBFS marginally, it remains significant at the 5 percent confidence level.

Table 6. Results for the Cross-Section

\begin{tabular}{|c|c|c|c|c|c|c|}
\hline & \multicolumn{2}{|c|}{ Specification A } & \multicolumn{2}{|c|}{ Specification B } & \multicolumn{2}{|c|}{ Specification C } \\
\hline & $\begin{array}{c}\text { Coefficient } \\
\text { Estimate }\end{array}$ & $\begin{array}{l}\text { Standard } \\
\text { Error }\end{array}$ & $\begin{array}{c}\text { Coefficient } \\
\text { Estimate }\end{array}$ & $\begin{array}{c}\text { Standard } \\
\text { Error }\end{array}$ & $\begin{array}{l}\text { Coefficient } \\
\text { Estimate }\end{array}$ & $\begin{array}{l}\text { Standard } \\
\text { Error }\end{array}$ \\
\hline $\mathrm{CBFS}_{1}$ & $-.0010^{\star \star \star}$ & .00038 & $-.0008^{\star \star \star}$ & .00034 & $-.0008^{*}$ & .00041 \\
\hline Openness & -.0245 & .02159 & -.0170 & .02277 & -.0383 & .03530 \\
\hline Institutions & $-.0211^{\star \star}$ & .00880 & -.0073 & .01356 & -.0245 & .01510 \\
\hline GDP per capita & & & $-.0000^{*}$ & .00000 & & \\
\hline Turnover rate & & & & & .0046 & .05173 \\
\hline Constant & $.1737^{\star \star \star}$ & .02214 & $.1562^{\star \star \star}$ & .02654 & 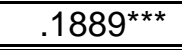 & .02829 \\
\hline Observations & \multicolumn{2}{|c|}{97} & \multicolumn{2}{|c|}{97} & \multicolumn{2}{|c|}{56} \\
\hline$R$-squared & \multicolumn{2}{|c|}{.14} & \multicolumn{2}{|c|}{.16} & \multicolumn{2}{|c|}{.11} \\
\hline
\end{tabular}

The third column in Table 6 presents results after adding a proxy for de facto central bank independence, namely the central bank turnover rate for the period 1990-1998, to the first specification. This reduces the number of observations substantially, to 56 if observations with inflation exceeding 100 percent are excluded. Parameter estimates for CBFS remain largely stable, and significant at the 10 percent confidence level. However, the proxy for CBI does not seem to explain well the observed cross-country variation in inflation.

As extensively discussed in the literature on central bank independence (see in particular De Haan and Sturm, 2001), the empirical relationship between inflation and structural measures of the central bank's positioning relative to the rest of the public sector might depend strongly on the inclusion of high inflation countries. Following De Haan and Sturm, we therefore present results in a "recursive way", sequentially adding observations with higher inflation rates.

Figure 10 presents results for these recursive exercises for the three specifications in Table 6. It is apparent that the coefficient estimates for $\mathrm{CBFS}_{1}$ are indeed sensitive to the successive inclusion of observations with higher inflation. In particular for the range of inflation rates between 5 and 15 percent, adding few observations to the sample results in moving from a statistically significant relationship (at $\pi<5 \%$ ) to an insignificant one (at $\pi<10 \%$ ). However, from this point on, parameter estimates converge, and the 95 percent confidence interval remains in territories implying a negative relation between CBFS and inflation. Adding the turnover rate widens the confidence band somewhat, but does not fundamentally change the overall conclusion.

Apart from sensitivity to inflation outliers, results could be driven by very large positive or negative values for our proxy for CBFS. This is particularly true for the IFS data, as some of the observations appear to capture episodes in which accounting information has basically not been available, leading to extreme negative or positive values for OIN. Table 7 therefore 
shows results for a case in which we restrict the ratio of the sum of capital and OIN to total assets to $+/$ - 50 percent. The results suggest that taking out extreme observations substantially strengthens the observed relationship between CBFS and inflation.

Table 7. Accounting for Extreme Cases of Balance Sheet Distortions

\begin{tabular}{|c|c|c|c|c|c|c|}
\hline & \multicolumn{2}{|c|}{ Specification A } & \multicolumn{2}{|c|}{ Specification B } & \multicolumn{2}{|c|}{ Specification C } \\
\hline & $\begin{array}{c}\text { Coefficient } \\
\text { Estimate }\end{array}$ & $\begin{array}{l}\text { Standar } \\
\text { d Error }\end{array}$ & $\begin{array}{l}\text { Coefficient } \\
\text { Estimate }\end{array}$ & $\begin{array}{l}\text { Standard } \\
\text { Error }\end{array}$ & $\begin{array}{c}\text { Coefficient } \\
\text { Estimate }\end{array}$ & $\begin{array}{c}\text { Standard } \\
\text { Error }\end{array}$ \\
\hline $\mathrm{CBFS}_{1}$ & $-.0018^{\star \star \star}$ & .0005 & $-.0016^{\star \star \star}$ & .0003 & $-.0020^{\star \star \star}$ & .0008 \\
\hline Openness & -.0213 & .0227 & -.0169 & .0228 & -.0229 & .0412 \\
\hline Institutions & $-.0181^{\star \star}$ & .0087 & -.0096 & .0136 & $-.0096^{\star}$ & .0150 \\
\hline GDP per capita & & & -.0000 & .0000 & & \\
\hline Turnover rate & & & & & -.0151 & .0512 \\
\hline Constant & $.176^{\star \star \star}$ & .023 & $.164^{\star \star \star}$ & .023 & $.197^{\star \star \star}$ & .029 \\
\hline Observations & \multicolumn{2}{|l|}{93} & \multicolumn{2}{|c|}{93} & \multicolumn{2}{|c|}{52} \\
\hline$R$-squared & \multicolumn{2}{|c|}{.17} & \multicolumn{2}{|c|}{.18} & \multicolumn{2}{|c|}{.16} \\
\hline
\end{tabular}

Closely related to the potential problems raised by outliers, Stella (2008) argues that it is unlikely that a significant statistical relationship between CBFS and price stability can be established for relatively high values for the explanatory variable. Intuitively, the central bank's aversion to incur the cost for aggressively reacting to inflation pressures will only become relevant when balance sheet restrictions become severe enough to represent a binding constraint. To test this assertion, we again follow the approach depicted in Figure 10. Instead of ordering observations according to the observed inflation rate, however, we expand the sample size along the dimension of CBFS itself: Starting with a sub-sample that only includes those countries with, on average, relatively healthy balance sheets, observations with exceedingly negative values for $\mathrm{CBFS}_{1}$ are added sequentially.

As can be seen from Figure A2 in the Appendix, the results indeed appear to support the hypothesis that only a relatively strong impairment of the central bank's balance sheet will result in a significant worsening of macroeconomic performance: The negative coefficient for $\mathrm{CBFS}_{1}$ only becomes significant when observations for which the value of $\mathrm{CBFS}_{1}$ is below a certain threshold are included in the sample (in the shaded area to the right of Figure A2). In the example forming the basis for Figure A2, this threshold value is around 5 percent. $^{29}$

\footnotetext{
${ }^{29}$ It should be noted that samples restricted to very high values for $\mathrm{CBFS}_{1}$ are rather small, limiting the scope for meaningful interference. In Figure A1, for example, only 16 countries reported values of 25 or above. However, sample size increases quite rapidly when the threshold value below which observations are excluded is lowered, and already ranges between 40 and 50 observations in the "critical" bracket in which coefficient estimates become significant.
} 
Figure 10. Relationship Between Central Bank Financial Strength ${ }_{1}$ and $d$

Recursive Regressions for Relationship between $\mathrm{CBFS}_{1}$ and $d$

(Covariates: Bureaucratic Quality and Openness)

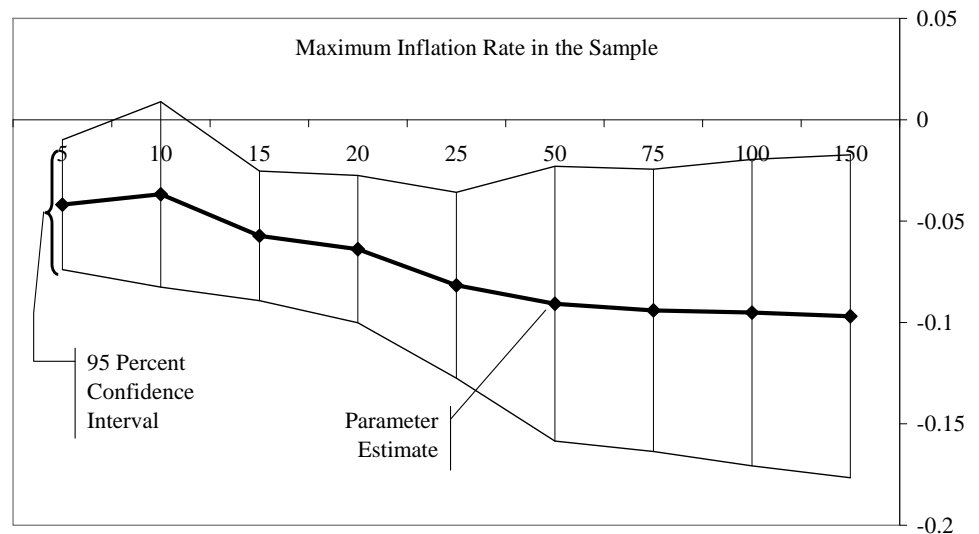

Recursive Regressions for Relationship between CBFS $_{\mathbf{1}}$ and $\boldsymbol{d}$

(Covariates: Bureaucratic Quality, Openness, and GDP per capita)

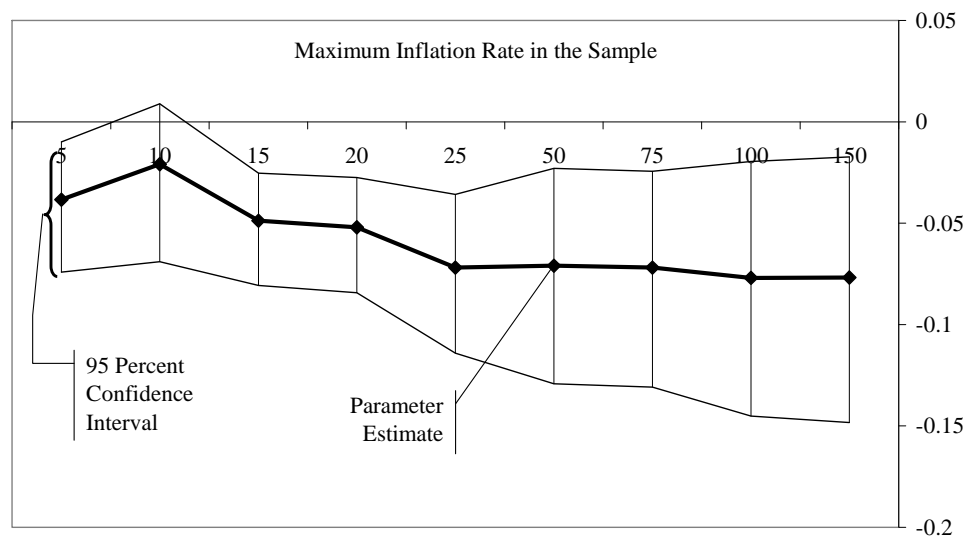

Recursive Regressions for Relationship between $\mathrm{CBFS}_{1}$ and $d$

(Covariates: Bureaucratic Quality, Openness, and CB TOR)

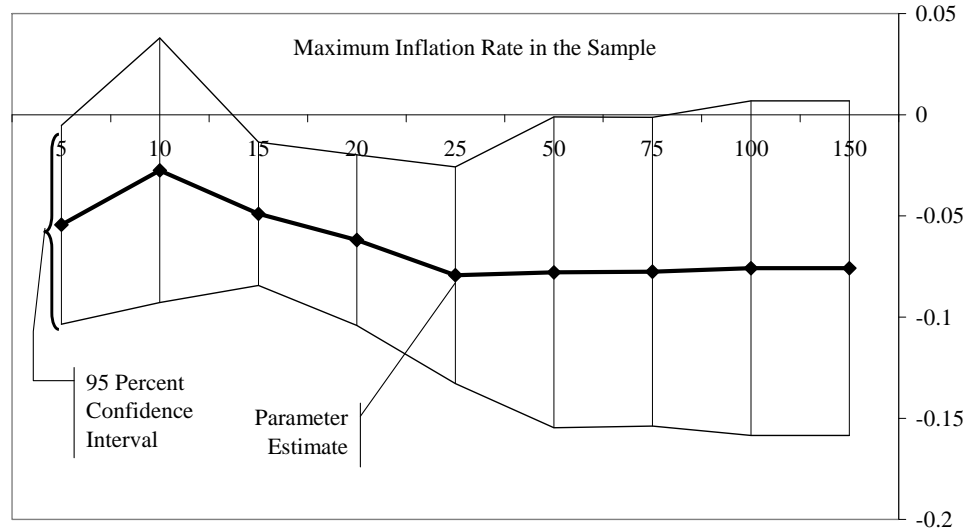


Figure 11. Relationship Between Central Bank Financial Strength ${ }_{2}$ and $d$

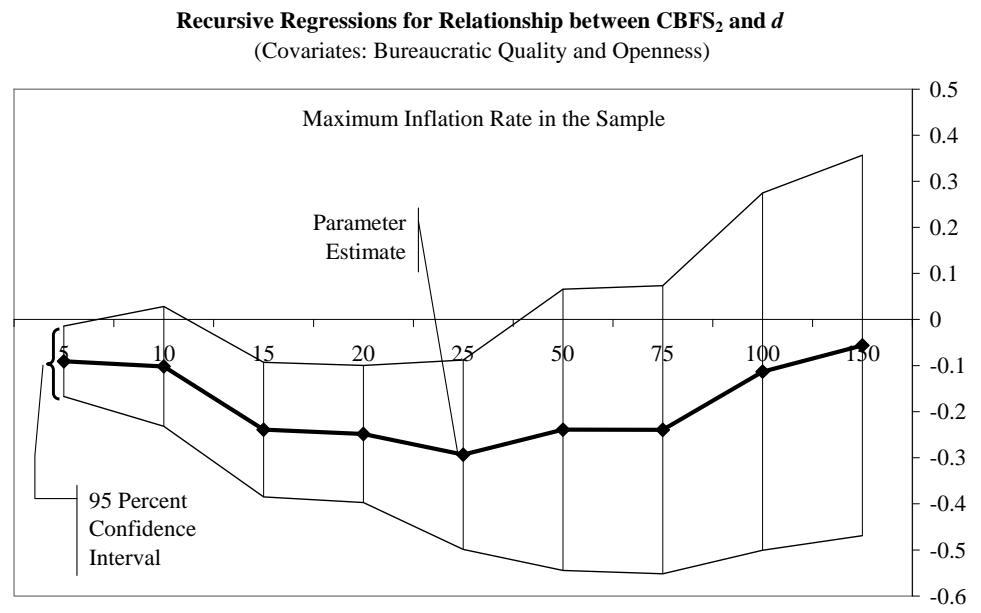

Recursive Regressions for Relationship between $\mathrm{CBFS}_{2}$ and $\boldsymbol{d}$

(Covariates: Bureaucratic Quality, Openness, and GDP per capita)

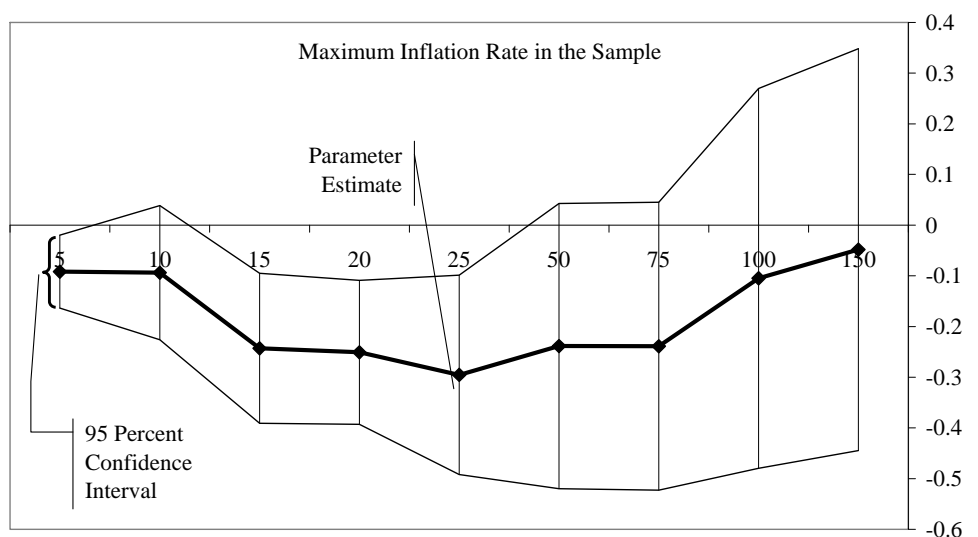

Recursive Regressions for Relationship between $\mathrm{CBFS}_{2}$ and $d$

(Covariates: Bureaucratic Quality, Openness, and CB Turnover Rate)

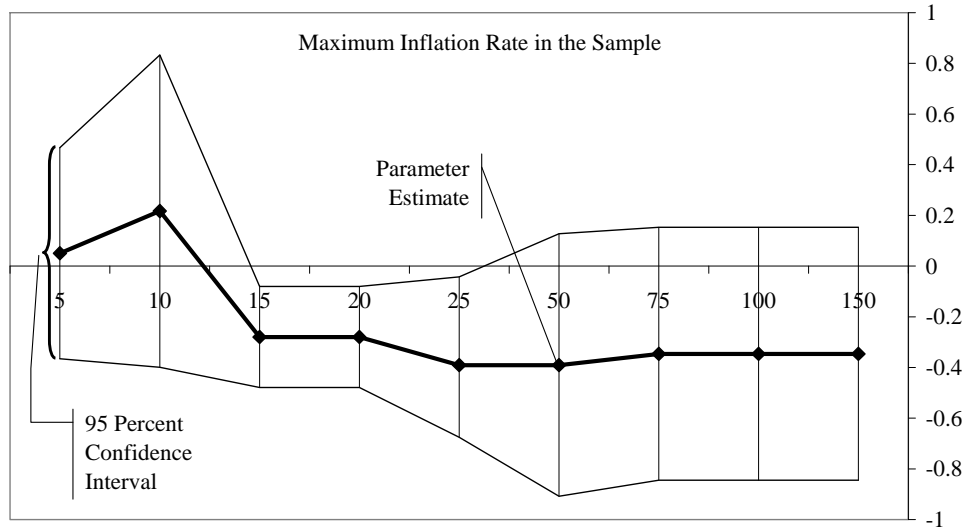


In a final step, we repeated the estimations above, replacing our stock measure of CBFS with $\mathrm{CBFS}_{2}$, i.e., the return on average assets. As shown in Figure 11, using this alternative measure results in substantially higher sensitivity of parameter estimates to a change in sample composition. In particular, while having the expected sign, the coefficient for CBFS only becomes significant after ignoring observations in which the inflation rate exceeds a certain threshold. More specifically, the $p$-value falls below 10 percent only if the sample is restricted to observations in which average inflation is below 75 percent.

\section{Policy Conclusions ANd Future Research}

The analysis above presents first and preliminary steps toward establishing a firmer link between CBFS and policy performance. The econometric results are consistent with case study evidence, and suggest that weak central bank finances might indeed negatively impact the ability of policymakers to react to inflationary pressures effectively. For policymakers in countries that are currently experiencing sustained central bank losses, this means that efforts to bring central bank finances back on a safe footing are likely to be worth the fiscal costs that usually accompany central bank recapitalization efforts, in particular if the potential additional benefits, for example with respect to domestic debt market development, are taken into account.

Combining the econometric results of section IV with the empirical evidence presented in section III, it becomes clear that there is a need for central banks and their stakeholders to ask whether existing funding modes are sustainable over the longer term. Though many observers have suspected that recent years saw a decline in central bank profitability, our study is among the first to document this trend using time series evidence. It is probably too early to declare an erosion of traditional models of central bank financing, in particular because the (still incomplete) data for 2005 and 2006 could be viewed as an indication of a slowing trend or even a trend reversal. Nonetheless, a review of central bank funding modes appears to be a promising area of further investigation.

Our analysis also points to a relatively large number of open issues on which further research is necessary to firm up these policy conclusions. On the empirical level, an important next step would be to look at other measures of central bank performance, in particular measures of financial repression. Moreover, future studies will have to disentangle better the complex structure of causes and effects, asking whether it is primarily a lack of central bank independence, potentially combined with fiscal dominance that leads to low CBFS, or whether CBFS itself is one of the major determinants of political and economic independence. Closely related, issues of endogeneity will have to be assessed more thoroughly, taking into account the circumstances under which central banks end up in a financially vulnerable situation. Finally, while this study has relied on cross-sectional and panel approaches, time series techniques could usefully complement the evidence presented here, for example by looking at the effects of central bank recapitalization efforts. In the time 
series context, it would also be interesting to use as dependent variables measures that capture central bank activism more directly.

A pre-condition for carrying out additional empirical research will be to expand and improve available data on CBFS. Since an inquiry into the areas outlined above is likely to require panel data, a first step would be to extend the dataset on Latin America and the Caribbean to a broader set of countries in the region, and eventually to other regions in the world. Perhaps more importantly, it will be necessary to improve upon the conceptualizations of CBFS, by developing measures of CBFS that come closer to existing theoretical concepts, such as the central bank net worth. To this end, there might be a need to go beyond accounting conventions to incorporate elements such as franchise value or implicit liabilities from future financial stability events.

Finally, we believe that there is scope to improve our understanding on the theory level. First, there is a need to develop a theory of central bank "corporate" governance, modeling monetary authorities' bureaucratic incentives and their relation to CBFS. The central bank's ability to create the means for paying its own liabilities leaves it in a unique position, the implications of which with respect to control right allocation and optimal intervention schemes have not been analyzed thoroughly enough. Second, it would be an important step forward to clarify in more detail in what sense issues of CBFS complement macroeconomic theories emphasizing the nexus between fiscal and monetary policies as a necessary ingredient for price level determination (Sims, 2004). More generally, future studies should focus on the exact channel linking CBFS and inflation, differentiating between the role of trust and inflation expectations, the potential indeterminacy of the price level without fiscal backing, and the role of soft budget constraints in shaping central bankers' incentives. 


\section{APPENDIX: STATISTICAL INFORMATION AND FIGURES}

\section{Table A1. Conceptualizations of Central Bank Financial Strength}

\begin{tabular}{l|l|l}
\hline \hline Concept & Description & Sources \\
\hline \hline CBFS $_{1}$ & $\begin{array}{l}\text { Sum of central bank capital (CBC) } \\
\text { and other items net (OIN), divided by } \\
\text { average total central bank assets } \\
(\text { TA). }\end{array}$ & $\begin{array}{l}\text { IMF International Financial } \\
\text { Statistics (IFS) and "Monetary and } \\
\text { Banking Statistics" and authors' } \\
\text { calculation }\end{array}$ \\
\hline CBFS $_{2}$ & $\begin{array}{l}\text { Central bank Return on Average } \\
\text { Assets (ROAA), defined as the ratio } \\
\text { of net income per annum divided by } \\
\text { average total assets }\end{array}$ & $\begin{array}{l}\text { Bureau van Dijk (Bankscope) and } \\
\text { authors' calculation }\end{array}$ \\
\hline CBFS $_{3}$ & $\begin{array}{l}\text { Central bank profits/losses as a } \\
\text { percentage of GDP }\end{array}$ & See Table A3 \\
\hline CBFS $_{4}$ & $\begin{array}{l}\text { Sum of CBFS } \\
\text { two, three, or four years respectively. }\end{array}$ & $\begin{array}{l}\text { Authors' calculation based on } \\
\text { information in Table A3 }\end{array}$ \\
\hline \hline
\end{tabular}

Table A2. Data Sources and Descriptions

\begin{tabular}{l|l|l}
\hline \hline Variable & Description & Sources \\
\hline \hline Inflation & Annual Change in Consumer Price Index & IMF IFS \\
\hline GDP per capita & GDP per capita (PPP) & IMF World Economic Outlook (WEO) \\
\hline World Inflation & $\begin{array}{l}\text { Average Annual Change in Consumer } \\
\text { Price Index of G7 economies }\end{array}$ & IMF IFS, and Authors' Calculation \\
\hline $\begin{array}{l}\text { Institutional } \\
\text { Quality }\end{array}$ & Indicator variable ranging from 0 to 100 & $\begin{array}{l}\text { The PRS Group, Inc., International } \\
\text { Country Risk Guide (ICRG) }\end{array}$ \\
\hline $\begin{array}{l}\text { Bureaucratic } \\
\text { Quality }\end{array}$ & Indicator variable ranging from 0 to 4 & ICRG \\
\hline $\begin{array}{l}\text { Democratic } \\
\text { Accountability }\end{array}$ & Indicator variable ranging from 0 to 6 & ICRG \\
\hline $\begin{array}{l}\text { Government } \\
\text { Stability }\end{array}$ & Indicator variable ranging from 0 to 12 & ICRG \\
\hline Corruption & Indicator variable ranging from 0 to 6 & ICRG \\
\hline Law and Order & Indicator variable ranging from 0 to 6 & ICRG \\
\hline Openness & (Exports + Imports)/GDP & IMF WEO and authors' calculations \\
\hline \hline
\end{tabular}




\begin{tabular}{l|l|l}
\hline \hline Banking Crisis & $\begin{array}{l}\text { Dummy variable taking a value of } 1 \text { in } \\
\text { which systemic banking crisis is taking } \\
\text { place }\end{array}$ & Caprio and Klingenbiel (2003) \\
\hline Fixed Regime & $\begin{array}{l}\text { Dummy Variable taking a value of } 1 \text { if de } \\
\text { jure exchange rate regime is described as } \\
\text { fixed }\end{array}$ & $\begin{array}{l}\text { Ghosh, Gulde, and Wolf (2002) and IMF } \\
\text { Annual Report REAER (various issues) }\end{array}$ \\
\hline CB TOR & Turnover rate for central bank governors & De Haan and Sturm (2001) \\
\hline Deficit & $\begin{array}{l}\text { General Government Balance in Percent } \\
\text { of GDP }\end{array}$ & IMF IFS and World Economic Outlook \\
\hline \hline
\end{tabular}


Table A3. Raw Data for Latin America Panel

Table A1. Central Bank Losses in a Group of Western Hemisphere Countries, 1987-2005 (In percent of GDP)

\begin{tabular}{|c|c|c|c|c|c|c|c|c|c|c|c|c|c|c|c|c|c|c|c|}
\hline Country & 1987 & 1988 & 1989 & 1990 & 1991 & 1992 & 1993 & 1994 & 1995 & 1996 & 1997 & 1998 & 1999 & 2000 & 2001 & 2002 & 2003 & 2004 & 2005 \\
\hline Argentina & -0.7 & -0.5 & -4.5 & -0.7 & -0.4 & -0.1 & 0.4 & 0.2 & 0.2 & 0.3 & 0.3 & 0.3 & 0.2 & 0.3 & -0.1 & $\ldots$ & $\ldots$ & $\ldots$ & $\ldots$ \\
\hline Bolivia & $\ldots$ & -0.2 & -0.4 & -0.7 & -0.7 & -0.2 & 0.4 & 0.7 & 0.9 & 0.6 & 0.7 & 0.7 & 0.4 & 0.5 & 0.5 & 0.5 & 0.2 & 0.3 & $0.3 *$ \\
\hline Chile & -3.1 & -3.2 & -1.8 & -2.2 & -1.1 & -1.2 & -1.0 & -0.9 & -0.6 & -0.7 & -1.1 & -1.1 & -1.1 & -1.4 & -1.0 & -1.2 & -0.7 & -0.8 & -0.5 \\
\hline Costa Rica & -3.5 & -3.3 & -2.8 & -2.0 & -1.9 & -2 & -1.5 & -1.4 & -1.9 & -2.1 & -1.8 & -1.6 & -1.6 & -1.8 & -1.2 & -1.4 & -1.6 & -1.3 & $-1.4 *$ \\
\hline Dominican Republic & -1.0 & -1.5 & -0.8 & -0.6 & 0.0 & -0.6 & -0.1 & -0.6 & -0.5 & -0.6 & -0.7 & -0.5 & -0.4 & -0.3 & -0.2 & -0.3 & -2.6 & -4.0 & -2.9 \\
\hline Ecuador & $\ldots$ & -2.2 & -2.5 & -2.9 & -2.3 & -1.0 & 0.1 & 0.6 & 0.0 & 0.2 & 0.1 & 0.3 & -1.2 & 0.6 & $\ldots$ & $\ldots$ & $\ldots$ & $\ldots$ & $\ldots$ \\
\hline Guatemala & -1.6 & -1.9 & -1.5 & -2.4 & -1.6 & -1.2 & -1.1 & -1.3 & -1.0 & -1.2 & -0.8 & -0.3 & -0.3 & -0.4 & -0.8 & -0.6 & -0.5 & -0.6 & $-0.5^{1}$ \\
\hline Haiti & $\cdots$ & $\ldots$ & $\ldots$ & $\ldots$ & $\ldots$ & $\cdots$ & $\ldots$ & $\cdots$ & $\cdots$ & $\cdots$ & $\cdots$ & 0.1 & 0.0 & -0.2 & -0.2 & -0.3 & -0.6 & -1.0 & ... \\
\hline Honduras & $\cdots$ & $\ldots$ & $\ldots$ & -3.2 & -2.5 & -2.7 & -0.5 & -1.3 & -1.9 & -1.6 & -1.6 & -0.1 & -0.2 & 0.0 & -0.4 & -0.9 & -1.1 & -1.1 & $-1.0 *$ \\
\hline Jamaica $^{2}$ & -5.7 & -5.4 & -5.4 & -5.0 & -4.3 & -5.6 & -4.7 & -1.8 & -2.0 & 0.6 & 1.0 & -0.3 & 0.0 & 0.3 & -0.5 & -1.7 & -1.7 & -1.0 & -1.5 \\
\hline Nicaragua & -5.0 & -8.0 & -13.8 & -2.8 & -0.7 & -1.1 & -1.4 & -0.6 & 0.1 & -0.2 & -0.6 & -3.3 & -1.7 & -1.6 & -1.3 & -2.0 & -1.6 & -1.4 & $\ldots$ \\
\hline Paraguay & 0.2 & 0.2 & 0.1 & 0.6 & 0.8 & 0.5 & 0.1 & 0.0 & -3.8 & -1.5 & -1.8 & -0.6 & -0.8 & -0.4 & -1.3 & -1.4 & -1.1 & -0.8 & $-0.2 *$ \\
\hline Peru & -5.4 & -3.2 & -0.4 & -1.1 & -0.4 & -0.2 & -0.2 & 0.0 & 0.0 & 0.0 & 0.1 & 0.1 & 0.1 & 0.0 & 0.2 & 0.2 & 0.1 & 0.0 & $-0.1 *$ \\
\hline Uruguay & -2.8 & -3.1 & -3.4 & -3.6 & -2.2 & -1.6 & -0.8 & -0.6 & -0.6 & -0.5 & -0.5 & -0.5 & -0.2 & -0.4 & -0.3 & -0.3 & 0.0 & -0.6 & $\cdots$ \\
\hline Venezuela & -1.4 & -2.9 & -1.8 & -2.0 & -1.7 & 0.0 & -0.2 & -2.0 & -1.0 & -0.7 & -0.6 & -0.8 & -0.5 & 0.3 & 0.1 & 0.1 & 0.8 & 1.6 & $\ldots$ \\
\hline Mean & -2.7 & -2.7 & -3.0 & -2.0 & -1.4 & -1.2 & -0.7 & -0.6 & -0.9 & -0.5 & -0.5 & -0.5 & -0.5 & -0.3 & -0.5 & -0.7 & -0.8 & -0.8 & -1.0 \\
\hline Median & -2.8 & -2.9 & -1.8 & -2.1 & -1.4 & -1.1 & -0.4 & -0.6 & -0.6 & -0.6 & -0.6 & -0.3 & -0.3 & -0.2 & -0.4 & -0.6 & -0.7 & -0.8 & -0.8 \\
\hline
\end{tabular}

Sources: Leone (1994), IMF staff reports, Central Bank of Argentina, Central Bank of Guatemala, Central Bank of Paraguay, Central Bank of Uruguay, Central Bank of Venezuela

* Preliminary

/1 IMF staff estimate

/2 For years after 2002, only includes Bank of Jamaica (BoJ) cash losses, excluding BoJ Special Issue Bond 


\section{Table A4. Selected Pair-wise Correlations for the Latin American Panel}

\begin{tabular}{|c|c|c|c|c|c|c|c|c|c|c|}
\hline & INF & FISCAL & OPEN & FIX & INQ & GDP & CRISIS & CBI1 & TOR & CBFS3 \\
\hline FISCAL & $\begin{array}{l}-0.1007 \\
0.0425\end{array}$ & & & & & & & & & \\
\hline OPEN & $\begin{array}{l}-0.0811 \\
0.0920\end{array}$ & $\begin{array}{l}-0.2218 \\
0.0000\end{array}$ & & & & & & & & \\
\hline FIX & $\begin{array}{l}-0.0782 \\
0.0922\end{array}$ & $\begin{array}{l}-0.1247 \\
0.0110\end{array}$ & $\begin{array}{l}0.2415 \\
0.0000\end{array}$ & & & & & & & \\
\hline INQ & $\begin{array}{l}-0.3217 \\
0.0000\end{array}$ & $\begin{array}{l}0.2412 \\
0.0000\end{array}$ & $\begin{array}{l}0.0905 \\
0.0684\end{array}$ & $\begin{array}{l}-0.0590 \\
0.2186\end{array}$ & & & & & & \\
\hline GDP & $\begin{array}{l}-0.0911 \\
0.0497\end{array}$ & $\begin{array}{l}0.0915 \\
0.0624\end{array}$ & $\begin{array}{l}-0.0063 \\
0.8957\end{array}$ & $\begin{array}{l}0.2154 \\
0.0000\end{array}$ & $\begin{array}{l}0.5977 \\
0.0000\end{array}$ & & & & & \\
\hline CRISIS & $\begin{array}{l}0.2426 \\
0.0000\end{array}$ & $\begin{array}{l}0.0051 \\
0.9182\end{array}$ & $\begin{array}{l}-0.1122 \\
0.0185\end{array}$ & $\begin{array}{l}-0.1359 \\
0.0030\end{array}$ & $\begin{array}{l}-0.0896 \\
0.0614\end{array}$ & $\begin{array}{l}-0.0384 \\
0.4042\end{array}$ & & & & \\
\hline CBI & $\begin{array}{l}-0.1226 \\
0.0175\end{array}$ & $\begin{array}{l}0.0389 \\
0.4690\end{array}$ & $\begin{array}{l}-0.1051 \\
0.0438\end{array}$ & $\begin{array}{l}0.0601 \\
0.2405\end{array}$ & $\begin{array}{l}0.3561 \\
0.0000\end{array}$ & $\begin{array}{l}0.3583 \\
0.0000\end{array}$ & $\begin{array}{l}-0.0218 \\
0.6700\end{array}$ & & & \\
\hline TOR & $\begin{array}{l}0.1207 \\
0.0293\end{array}$ & $\begin{array}{l}-0.0842 \\
0.1412\end{array}$ & $\begin{array}{l}-0.2594 \\
0.0000\end{array}$ & $\begin{array}{l}-0.1387 \\
0.0122\end{array}$ & $\begin{array}{l}-0.1920 \\
0.0009\end{array}$ & $\begin{array}{l}-0.0921 \\
0.0968\end{array}$ & $\begin{array}{l}0.1968 \\
0.0003\end{array}$ & $\begin{array}{l}-0.3236 \\
0.0000\end{array}$ & & \\
\hline $\mathrm{CBFS}_{3}$ & $\begin{array}{l}-0.4192 \\
0.0000\end{array}$ & $\begin{array}{l}-0.2708 \\
0.0000\end{array}$ & $\begin{array}{l}-0.3118 \\
0.0000\end{array}$ & $\begin{array}{l}0.0590 \\
0.3530\end{array}$ & $\begin{array}{l}0.3027 \\
0.0000\end{array}$ & $\begin{array}{l}0.1160 \\
0.0672\end{array}$ & $\begin{array}{l}-0.1095 \\
0.0839\end{array}$ & $\begin{array}{l}0.2283 \\
0.0010\end{array}$ & $\begin{array}{l}-0.0934 \\
0.2201\end{array}$ & \\
\hline $\mathrm{CBFS}_{4}$ & $\begin{array}{l}-0.3614 \\
0.0000\end{array}$ & $\begin{array}{l}-0.2735 \\
0.0000\end{array}$ & $\begin{array}{l}-0.3186 \\
0.0000\end{array}$ & $\begin{array}{l}0.0223 \\
0.7246\end{array}$ & $\begin{array}{l}0.2094 \\
0.0008\end{array}$ & $\begin{array}{l}0.1170 \\
0.0643\end{array}$ & $\begin{array}{l}-0.0442 \\
0.4857\end{array}$ & $\begin{array}{l}0.2664 \\
0.0001\end{array}$ & $\begin{array}{l}-0.0021 \\
0.9782\end{array}$ & $\begin{array}{l}0.7958 \\
0.0000\end{array}$ \\
\hline
\end{tabular}

Table A5. Selected Pair-wise Correlations for the Cross-Country Sample

$\begin{array}{lcccccc} & \text { INF } & \text { OPEN } & \text { INQ } & \text { GDP } & \text { TOR } & \text { CBFS1 } \\ \text { OPEN } & -0.0932 & & & & & \\ & 0.2914 & & & & & \\ \text { INQ } & -0.2380 & 0.3239 & & & & \\ & 0.0060 & 0.0007 & & & & \\ \text { GDP } & -0.1292 & 0.3533 & 0.8255 & & & \\ & 0.1012 & 0.0000 & 0.0000 & & & \\ \text { TOR } & 0.3514 & 0.0147 & -0.0162 & -0.0627 & & \\ & 0.0016 & 0.9058 & 0.8971 & 0.5830 & & \\ \text { CBFS1 } & -0.3070 & 0.0802 & 0.2580 & 0.2717 & -0.1147 & \\ & 0.0001 & 0.3590 & 0.0027 & 0.0003 & 0.3140 & \\ \text { CBFS2 } & -0.0713 & -0.0241 & 0.2989 & 0.2898 & -0.1452 & 0.1964 \\ & 0.4354 & 0.8148 & 0.0021 & 0.0013 & 0.2601 & 0.0294\end{array}$

Notes: The table reports pair-wise correlations for variables in the Cross-Country Sample. Figures in italics below the correlation coefficient are significance levels for the null hypothesis that correlation is nil. Variables are abbreviated as follows (also see Table A1): INF=Inflation rate, Open= Openness, GDP=GDP per capita on a PPP basis, TOR=Central Bank Turnover Rate. 
Figure A 1. Price Stability and $\mathrm{CBFS}_{4}$

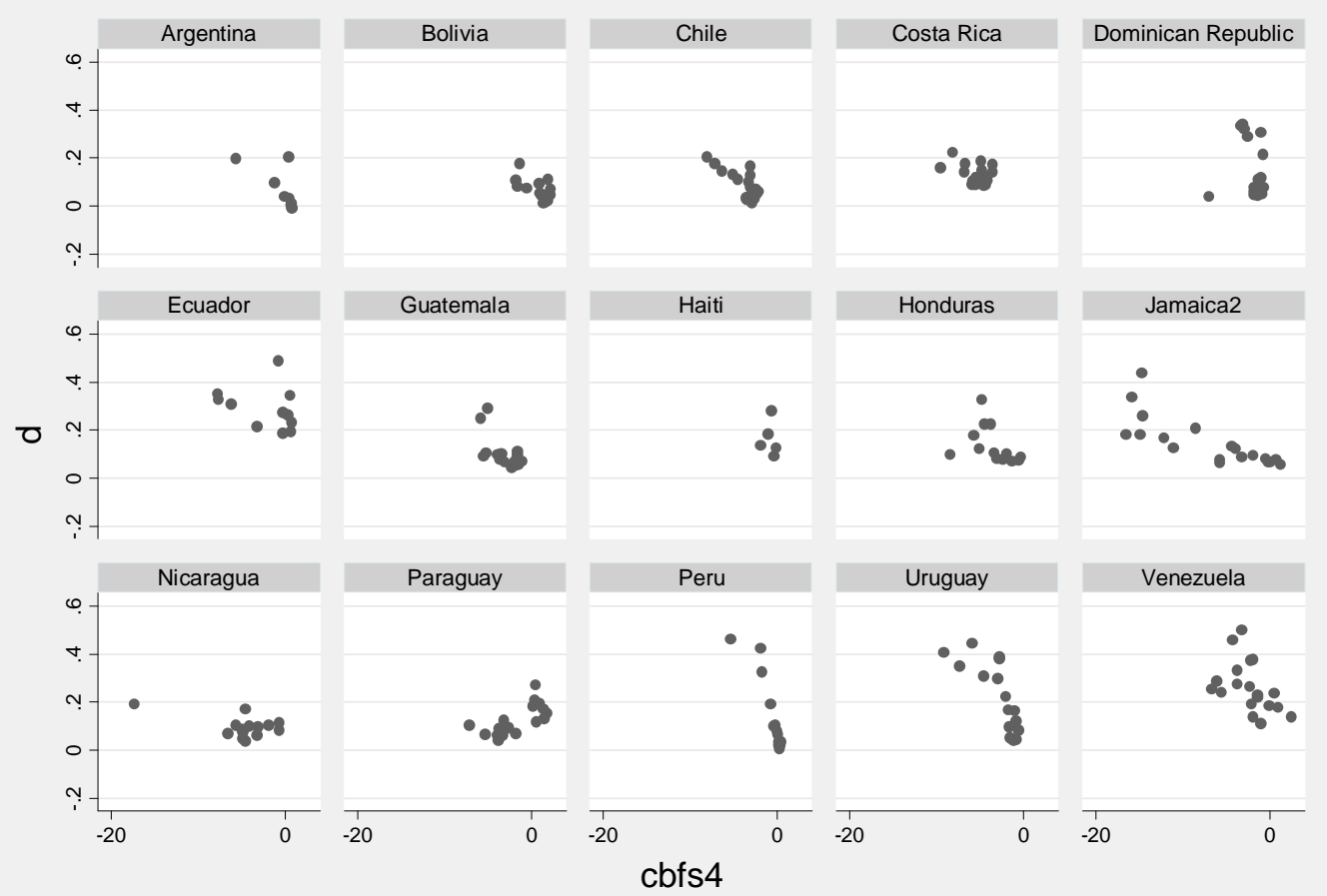

Graphs by Country

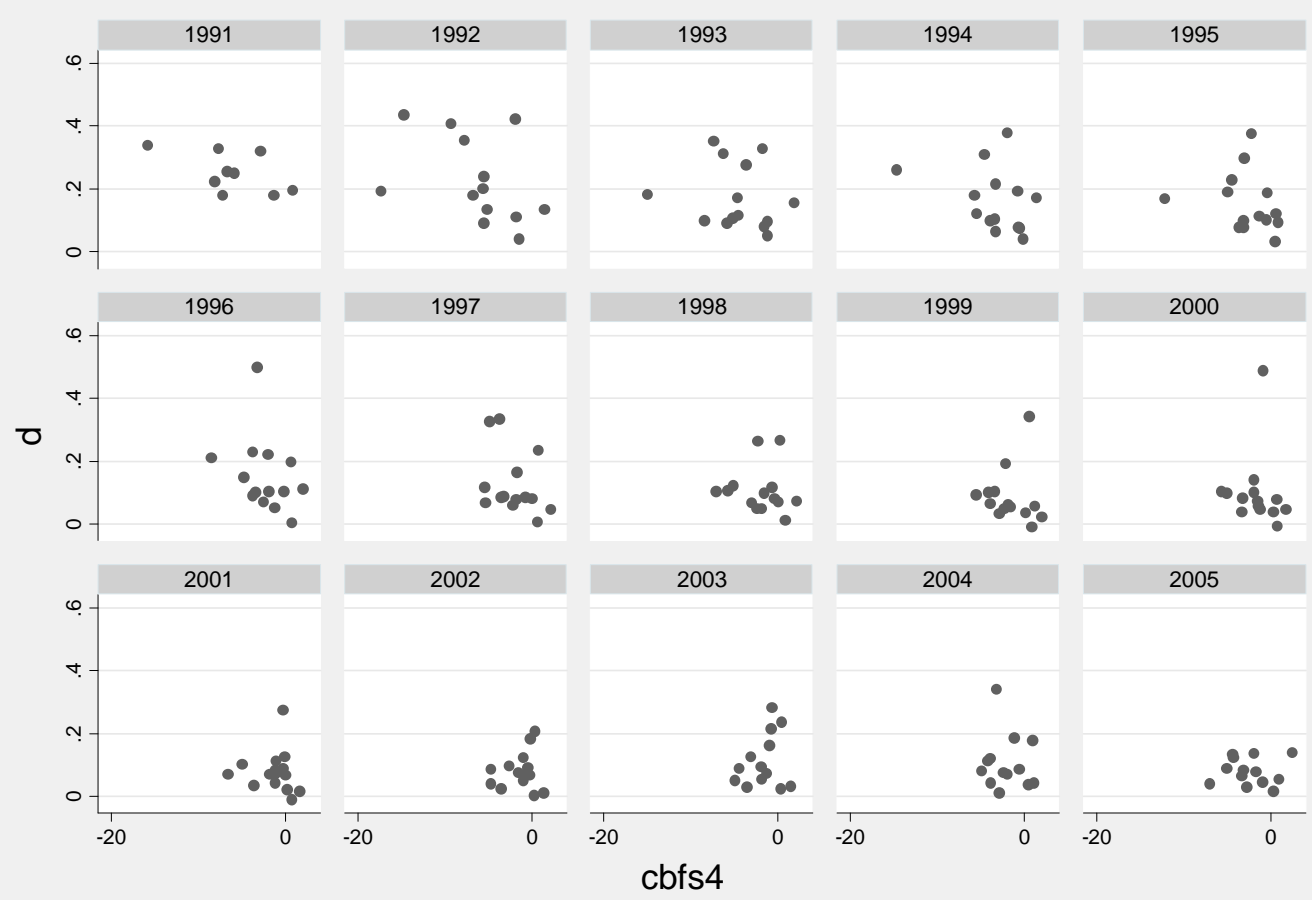

Graphs by Year 
Figure A 2. Robustness of Relationship between CBFS and Price Stability

Recursive Regression for Relationship between $\boldsymbol{d}$ and $\mathrm{CBFS}_{\mathbf{1}}$ (Covariates: Bureaucratic Quality and Openness)

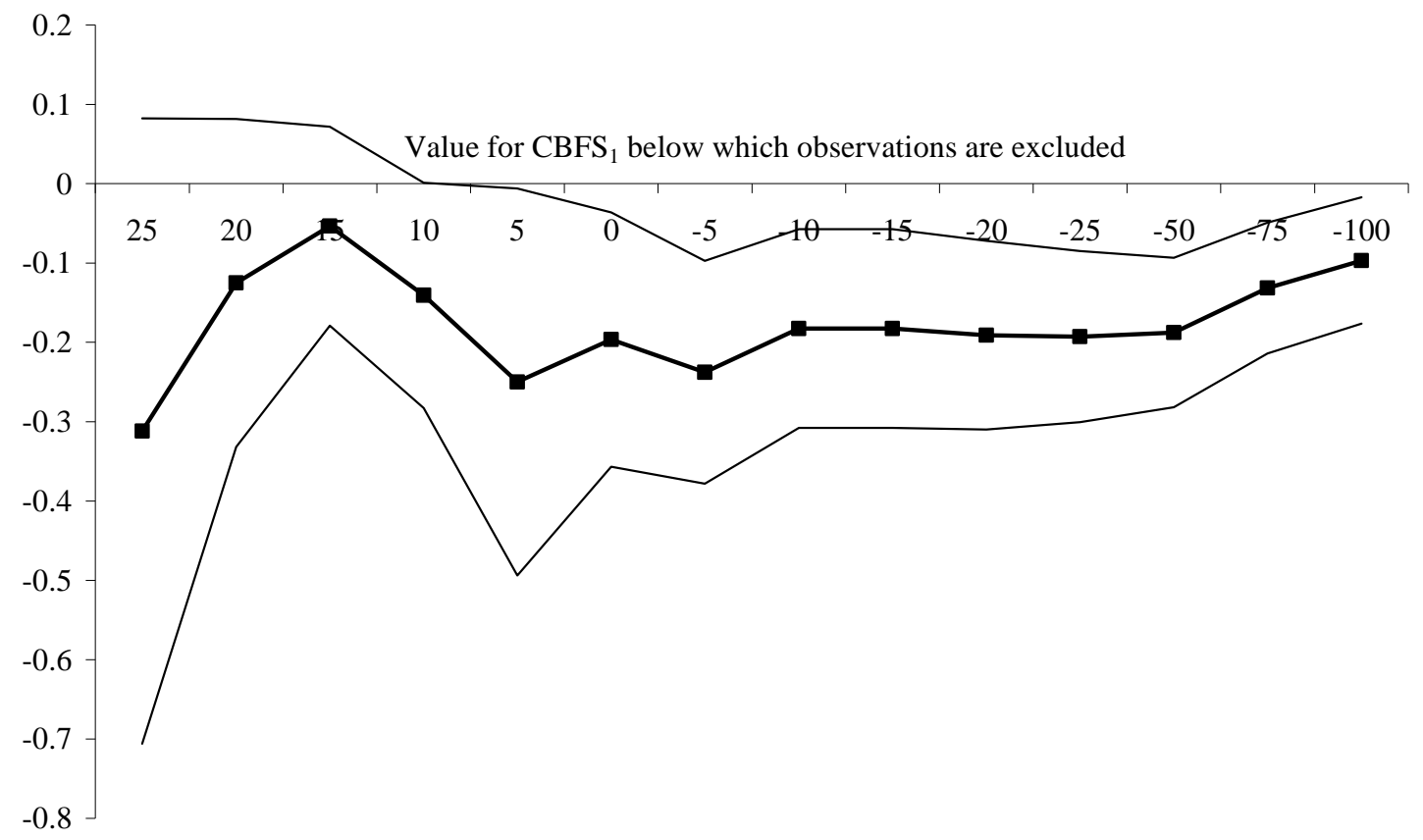




\section{REFERENCES}

Alfaro, Laura, 2005. "Inflation, openness, and exchange-rate regimes: The quest for shortterm commitment,” Journal of Development Economics, Elsevier, vol. 77(1), pages 229-249, June.

Arena, Marco, C. Reinhart, and F. Vázquez, 2006, “The Lending Channel in Emerging Economics: Are Foreign Banks Different?,” NBER Working Paper No. 12340, June 2006.

Arnone, Marco, Laurens, Bernard and Segalotto, Jean-François, 2006a, "The Measurement of Central Bank Autonomy: Survey of Models, Indicators, and Empirical Evidence,” (October 2006). IMF Working Paper 06/227 (Washington: International Monetary Fund).

Arnone, Marco, Laurens, Bernard and Segalotto, Jean-François, 2006b, “Measures of Central Bank Autonomy: Empirical Evidence for OECD, Developing, and Emerging Market Economies,” (October 2006), IMF Working Paper 06/228 (Washington: International Monetary Fund).

Bernanke, Ben S., 2003, “Some thoughts on monetary policy in Japan,” Paper presented to the Japan Society of Monetary Economics, Tokyo (May 31). Available at: http://www.federalreserve.gov/BoardDocs/Speeches/2003/20030531/default.htm

Bindseil, Ulrich, Manzanares, Andres, and Benedict Weller, 2004, "The Role of Central Bank Capital Revisited,” ECB Working Paper Series No. 392, September 2004 (Frankfurt: European Central Bank).

Campillo, Marta and Miron, Jeffrey A., 1996, "Why Does Inflation Differ Across Countries?,” (April 1996). NBER Working Paper No. W5540.

Cargill, Thomas F., 2005, "Is the Bank of Japan’s Financial Structure an Obstacle to Policy?,” Staff Papers, International Monetary Fund, Vol. 52, No. 2, (September), pp. 311-334.

Cukierman, A., 1992, CB Strategy, Credibility, and Autonomy (Cambridge, Massachusets: MIT Press).

Dalton, John and Claudia Dziobek, 2005, “Central Bank Losses and Experiences in Selected Countries,” IMF Working Paper 05/72 (Washington: International Monetary Fund).

De Haan, Jakob and Jan-Egbert Sturm, 2001, "Inflation in Developing Countries: Does Central Bank Independence Matter?,” CESifo Working Paper Series. 
Eggertsson, Gauti and Eric Le Borgne, 2005. "The politics of central bank independence: a theory of pandering and learning in government," Staff Reports 205, Federal Reserve Bank of New York.

Ernhagen, Tomas, Vesterlund, M., and Viotti, Staffan, 2002, "How much equity does a central bank need?” Sveriges Riksbank Economic Review 2002/2, 5-18.

Fitch Ratings, 2006, “Republic of Costa Rica: International Credit Analysis-Sovereigns” www.fitchratings.com, pp. 9-10, (October 5).

Frisell, Lars, Roszbach, Kasper F. and Spagnolo, Giancarlo, "Governing the Governors: A Clinical Study of Central Banks,” (March 2008). Riksbank Research Paper Series No. 21.

Fry, Maxwell J., 1993, “The Fiscal Abuse of Central Banks,” IMF Working Papers 93/58 (Washington: International Monetary Fund).

Fry, Maxwell J., 1998, “Assessing central bank independence in developing countries: do actions speak louder than words?,” Oxford Economic Papers 50 (1998), 512-529.

Grilli, V., D. Masciandaro, and G. Tabellini, 1991, "Political and Monetary Institutions and Public Financial Policies in the Industrial Countries,” Economic Policy, Vol. 13, pp. 341-92.

Gutiérrez, E., 2003, “Inflation Performance and Constitutional Central Bank Independence: Evidence from Latin America,” IMF Working Paper 03/53 (Washington: International Monetary Fund).

Hawkins, John, 2003, “Central Bank Balance Sheets and Fiscal Operations,” BIS Papers No. 20, 71-83.

Ize, Alain, 2005, “Capitalizing Central Banks: A Net Worth Approach,” Staff Papers, International Monetary Fund, Vol. 52, No. 2, (September).

Ize, Alain, 2006, “Spending Seigniorage: Do Central Banks Have a Governance Problem?” IMF Working Paper 06/58 (Washington: International Monetary Fund).

Jácome, Luis Ignacio, 2001, "Legal Central Bank Independence and Inflation in Latin America During the 1990s,” IMF Working Paper 01/212 (Washington: International Monetary Fund).

Jacome Luis Ignacio, and Francisco F. Vazquez, 2005. “Any Link Between Legal Central Bank Independence and Inflation? Evidence from Latin America and the Caribbean,” IMF Working Paper 05/75 (Washington: International Monetary Fund). 
Johnson, Grahame, and Mark Zelmer, 2007, "Implications of New Accounting Standards for the Bank of Canada’s Balance Sheet,” Bank of Canada Discussion Paper 2007-2.

Leone, Alfredo, 1993, “Institutional and Operational Aspects of Central Bank Losses,” IMF Paper on Policy Analysis and Assessment 93/14, September, (Washington: International Monetary Fund).

Lonnberg, Ake, and Peter Stella, 2008. "Issues in Central Bank Finance and Independence," IMF Working Paper 08/37 (Washington: International Monetary Fund).

Mackenzie, George A., and Peter Stella, 1996, “Quasi-Fiscal Operations of Public Financial Institutions,” IMF Occasional Paper No. 142 (Washington: International Monetary Fund, October).

Markiewicz, Malgorzata, 2001, "Quasi-fiscal operations of central banks in transition economies,” BOFIT Discussion Papers 2001 No. 2 (Helsiniki: Bank of Finland Institute for Economies in Transition).

Meltzter, A., 1999, “Comments: What More Can the Bank of Japan Do?,” Monetary and Economic Studies, 17 (3), Institute for Monetary and Economic Studies, Bank of Japan, December.

Posen, A.,1995, "Declarations are not enough: Financial Sector Sources of Central Bank Independence,” NBER Macroeconomics Annual. Cambridge, MA: M.I.T. Press.

Reuters Online, 2007 “S\&P Upgrades Dominican Republic Ratings on Reforms,” (September 4) http://www.reuters.com/article/bondsNews/idUSN0442185420070904

Rogoff, "The Optimal Degree of Commitment to an Intermediate Monetary Target,” Quarterly Journal of Economics 100 (November 1985), 1169-1189.

Romer, David, 1993, “Openness and Inflation: Theory and Evidence,” Quarterly Journal of Economics 58, 869-903.

Sims, Chris, 2004, "Fiscal Aspects of Central Bank Independence,” in: European Monetary Integration, edited by Hans-Werner Sinn, Mika Widgrén, and Marko Köthenbürger, 103-116.

Stella, Peter, 2005, “Central Bank Financial Strength, Transparency, and Policy Credibility,” Staff Papers, International Monetary Fund, Vol. 52, No. 2, (September), pp. 335-365.

Stella, Peter, 2008 “Central Bank Financial Strength, Policy Constraints and Inflation,” IMF Working Paper 08/49 (Washington: International Monetary Fund). 
Stella, Peter, forthcoming, "Varieties of Central Bank Recapitalization Experience,” forthcoming as: IMF Working Paper.

Ueda, Kazuo, 2004, “The Role of Capital for Central Banks,” Paper presented at a meeting of the Japan Society of Monetary Economics, Tokyo, October. Available at: http://www.boj.or.jp/en/type/press/koen/ko0402b.htm

Vaez-Zadeh, Reza, 1991, "Implications and remedies of central bank losses,” in Patrick Downes and Reza Vaez-Zadeh (eds), The evolving role of central banks, IMF, Washington DC.

Walsh, Carl E., 2005, Optimal Contracts for Central Bankers, American Economic Review, 85 (1), March. 